\title{
Measurement of Thermal Properties of Saltstone
}

by

J. L. Steimke

Westinghouse Savannah River Company

Savannah River Site

Aiken, South Carolina 29808

M. D. Fowley

\section{MASTER \\ $=$}

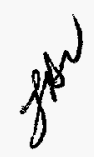

DIBTRBBUTION OF THS

DOOUNENT

This paper was prepared in connection with work done under the above contract number with the U.S.

Department of Energy. By acceptance of this paper, the publisher and/or recipient acknowledges the U.S.

Government's right to retain a nonexclusive, royalty-free license in and to any copyright covering this paper, along with the right to reproduce and to authorize others to reproduce all or part of the copyrighted paper. 


\section{DISCLAIMER}

This report was prepared as an account of work sponsored by an agency of the United States Government. Neither the United States Government nor any agency thereof, nor any of their employees, makes any warranty, express or implied, or assumes any legal liability or responsibility for the accuracy, completeness, or usefulness of any information, apparatus, product, or process disclosed, or represents that its use would not infringe privately owned rights. Reference herein to any specific commercial product, process, or service by trade name, trademark, manufacturer, or otherwise does not necessarily constitute or imply its endorsement, recommendation, or favoring by the United States Government or any agency thereof. The views and opinions of authors expressed herein do not necessarily state or reflect those of the United States Government or any agency thereof.

This report has been reproduced directly from the best available copy.

Available to DOE and DOE contractors from the Office of Scientific and Technical Information, P. O. Box 62, Oak Ridge, TN 37831; prices available from (423) 576-8401.

Available to the public from the National Technical Information Service, U. S. Department of Commerce, 5285 Port Royal Road, Springfield, VA 22161. 


\section{DISCLAIMER}

Portions of this document may be illegible in electronic image products. Images are produced from the best available original document. 
WSRC-TR-97-00357

\title{
MEASUREMENT OF THERMAL PROPERTIES OF SALTSTONE (U)
}

\author{
Authors: \\ J. L. Steimke and M. D. Fowley \\ May 1998
}

\section{Westinghouse Savannah River Company \\ Savannah River Technology Center Aiken, SC 29808}

Prepared for the United States Department of Energy under Contract DE-A C09-96SR18500 
KEYWORDS:

SALTSTONE

HYDRATION CONDUCTIVITY SPECIFIC HEATS

CALORIMETRY

CALORIMETERS

RETENTION:

PERMANENT

\section{MEASUREMENT OF THERMAL PROPERTIES OF SALTSTONE (U)}

Authors:

J. L. Steimke and M. D. Fowley

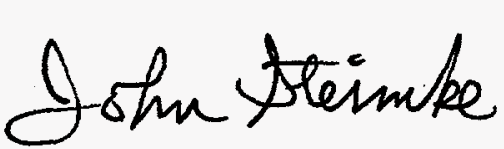
Mal Din

ISSUED: May 1998

SRTC SAVANNAH RIVER TECHNOLOGY CENTER, AIKEN, SC 29808

Westinghouse Savannah River Company

Prepared for the United States Department of Energy under Contract DE-AC09-96SR18500 
Document:

Title:
WSRC-TR-97-00357

Measurement of Thermal Properties of Saltstone (U)

Approvals

HN. Hewer

H. N. Guerrero, Technical Reviewer

$5 / 26 / 98$

Date:

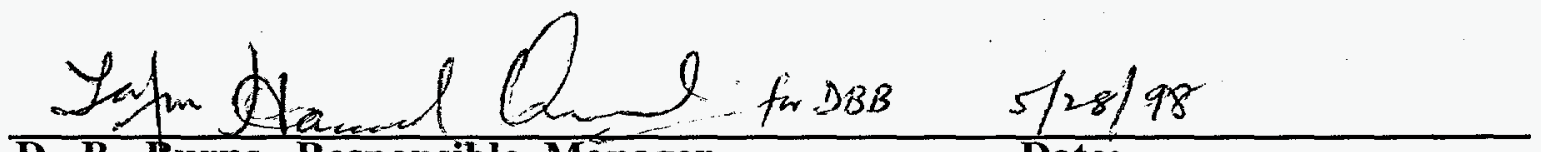
D. B. Burns, Responsible Manager Date:

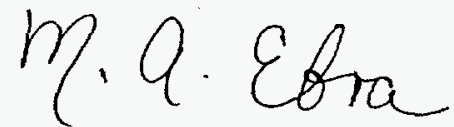

M. A. Ebra, Level 3 Manager

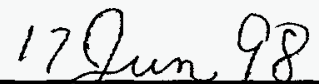


Radioactive liquid effluent from the In Tank Precipitation Process is mixed with Portland cement, flyash and furnace slag to form Saltstone. The Saltstone is poured into vaults at Z Area for long term disposal. A transient heat transfer model of the Saltstone pouring process was previously written to determine whether the Saltstone temperature would exceed the Technical Specification Limit of $95^{\circ} \mathrm{C}$. The present work was performed to provide Saltstone density, heat capacity, heat of hydration and thermal conductivity for inclusion in the model.

Density of Reference Saltstone was measured using the Archimedean technique of water immersion and determined to be $1.76 \pm 0.01 \mathrm{~g} / \mathrm{cm}^{3}$. Specific heat of Reference Saltstone was measured by mixing known masses of crushed Saltstone at room temperature and ethylene glycol at $100^{\circ} \mathrm{C}$ and measuring the resulting equilibrium temperature. The resulting specific heat was $0.304 \pm 0.01 \mathrm{cal} /{ }^{\circ} \mathrm{C} \mathrm{g}$ which agrees well with the literature.

Heat of hydration was measured using an adiabatic calorimeter. The calorimeter had been initially developed in 1995 and was further refined. The calorimeter has three nested dewars. The inner dewar contains the material to be tested and is plugged with a rubber stopper. The middle dewar is slightly larger and is inverted over the inner dewar to provide additional resistance to heat transfer and to provide an air pocket that helps to exclude ethylene glycol from the inner dewar. The outer dewar contains ethylene glycol, an electrical heater and an agitator. A differential thermocouple measures the temperature difference between the test material and the ethylene glycol. A solid state temperature controller adds sufficient heat to the outer dewar to make the temperature difference zero. The principal refinements in 1997 were to add an uninterruptible power supply, an emergency shutdown circuit and a more sophisticated temperature controller.

The calorimeter was checked in two ways. First, the inner dewar was filled with ethylene glycol at $100^{\circ} \mathrm{C}$ and no heat load. Ideally, the temperature would remain constant. The measured rate of drift was only $0.1^{\circ} \mathrm{C}$ per 100 hours which is excellent. Then a known electrical heat load of $29.9 \mathrm{~mW}$ was placed in the inner dewar. The measured rate of temperature increase agreed with the theoretical rate to within $\pm 4.3 \%$.

Calorimeter runs were made for both Reference Saltstone and a Low Cement Saltstone. The maximum heat of hydration for Reference Saltstone was 5 W/kg which occurred 12 hours after mixing. Twenty five hours after mixing the heat of hydration began to decay exponentially, decreasing from $0.13 \mathrm{~W} / \mathrm{kg}$ to $0.001 \mathrm{~W} / \mathrm{kg}$ at 950 hours. The equation for the exponential decay was $\log 10(\mathrm{Q})=-0.766-0.00232 \mathrm{t}$, where $\mathrm{t}$ (time) is in hours and $\mathrm{Q}$ (heat of hydration) is in W/kg. The Low Cement Saltstone had a slightly higher heat of hydration. Freshness of the cement, flyash and slag appears to be important with the fresher materials generating more heat.

Thermal conductivity was measured two ways. The primary method was to mold Saltstone around a thin cylindrical heater so that heat transfer was one-dimensional conduction. Heat input and temperatures at two radii were measured after thermal steady state had been achieved. The secondary and more approximate method was to mold Saltstone in a sphere 
around a central thermocouple. The sphere was immersed in boiling water which created a step change in surface temperature boundary condition. The temperature transient was recorded and analyzed. The two measured values of thermal conductivity were $1.06 \pm$ $0.06 \mathrm{~W} / \mathrm{m} \mathrm{K}$ and $0.95 \mathrm{~W} / \mathrm{m} \mathrm{K}$, respectively. 


\section{CONTENTS}

1. INTRODUCTION

1.1 Background

1.2 Previous work

2. MEASUREMENT OF SALTSTONE DENSITY 2

3. MEASUREMENT OF SALTSTONE SPECIFIC HEAT 2

4. MEASUREMENT OF HEAT OF HYDRATION

4.1 Description of Adiabatic Calorimeter

4.2 Instrumentation, Data Acquisition and Control

4.3 Shakedown Testing

4.4 Saltstone Calorimeter Runs

4.5 Analysis of Saltstone Calorimeter Data

2

2

3

4

6

7

5. MEASUREMENT OF THERMAL CONDUCTIVITY 10

5.1 Cylindrical Geometry

5.2 Spherical Geometry

10

11

6. CONCLUSIONS 11

7. ACKNOWLEDGMENTS 12

8. REFERENCES 12

9. FIGURES 13 


\section{INTRODUCTION}

\subsection{Background}

Low level radioactive salt solution from the In Tank Precipitation Process is mixed with Portland cement, flyash and furnace slag to form Saltstone. The Saltstone is poured into vaults at Z Area for long term disposal. The vaults are 100 feet square by 20 feet tall. For high Saltstone pouring rates and thick layers of Saltstone a large temperature increase can result because of heat of hydration. A transient heat transfer model of the Saltstone pouring process was previously written [Shadday, 1993] to determine whether the Saltstone temperature would exceed the Technical Specification Limit of $95^{\circ} \mathrm{C}$ and also to allow the comparison of different pouring strategies. The model requires the following properties of Saltstone as inputs: heat of hydration, specific heat, density and thermal conductivity. This experimental program was initiated to measure those quantities.

\subsection{Previous work}

The Department of Energy Hanford Site considered stabilizing low level liquid radioactive waste in a form similar to Saltstone. Lokken, et al. (PNL-7979) used an adiabatic calorimeter to measure the heat of hydration for a mixture of dry blend and simulated liquid waste. The dry blend consisted of $47 \mathrm{wt} \%$ fly ash, $47 \mathrm{wt} \%$ furnace slag and $6 \mathrm{wt} \%$ Portland cement. Nine pounds of dry blend were mixed with each gallon of waste. The calorimeter consisted of two dewars. The sample was held in the inner dewar which was stoppered. The inner dewar was placed in a larger dewar containing oil. Temperatures of the sample and the oil bath were measured separately and heat was added to the oil as necessary to equalize the two temperatures. Two calorimeter runs were made, starting at grout temperatures of $35^{\circ} \mathrm{C}$ and $45^{\circ} \mathrm{C}$. The grout in both runs reached a maximum temperature of $104^{\circ} \mathrm{C}$. The fact that both runs reached the same temperature was attributed to boiling which removed heat and prevented further increases in temperature. There was concern that the Hanford grout temperature limit would be exceeded during pouring of a large monolith because conduction heat transfer from the pour would be hindered. The authors also measured a grout thermal conductivity of $0.75 \mathrm{~W} / \mathrm{m} \mathrm{K}(0.43 \mathrm{btu} / \mathrm{hr} \mathrm{ft}$ $\left.{ }^{\circ} \mathrm{F}\right)$.

Because the first grout formulation exhibited a higher than expected heat of hydration Lokken (PNL-7859) tested dry blend with 40 wt \% limestone flour, $28 \mathrm{wt} \%$ fly ash, $28 \mathrm{wt} \%$ slag and 4 wt\% Portland cement. The limestone was expected to act as an inert diluent and reduce the heat of hydration. The simulated waste was $1.3 \mathrm{M}$ nitrate and $0.675 \mathrm{M}$ hydroxide plus other components. At 500 hours the adiabatic grout temperature, corrected for the specific heat of the dewar, was $95^{\circ} \mathrm{C}$ and rising. Therefore, the diluent effect of the limestone was not as large as anticipated.

Lokken (PNL-7860) tested two concepts to decrease the heat of hydration for the grout containing limestone. Diluting the waste by a factor of 100 decreased the temperature rise to $15^{\circ} \mathrm{C}$. Using acid to partially neutralize the hydroxide and decrease the $\mathrm{pH}$ to 13 also decreased the rate of temperature rise.

Bollinger [1996] used an adiabatic calorimeter in a scoping study to measure the heat of hydration for reference SRS Saltstone. His calorimeter was similar to the Lokken calorimeter but had two improvements. The first improvement was to use a differential thermocouple to measure the temperature difference between the contents of the sample dewar and the surrounding bath instead of measuring the two temperatures separately and then digitally subtracting the temperatures. The second improvement was to add a third dewar to the calorimeter which was inverted over the inner sample dewar. This reduced heat conduction through the rubber stopper in the sample dewar. When the run was terminated at 250 hours the temperature of Reference Saltstone was $90^{\circ} \mathrm{C}$ and increasing. 


\section{MEASUREMENT OF SALTSTONE DENSITY}

The Archimedean technique was used to measure the density of Reference Saltstone on

September 10, 1997 as follows. A $100 \mathrm{~mL}$ volumetric flask was weighed to determine its mass, $\mathrm{M}_{1}$. The flask was filled to the mark with water and weighed again. Using the known density of water at that temperature the calibration of the flask was verified. The flask was emptied and dried. Then the flask was nearly filled with broken pieces of Reference Saltstone and the flask was weighed again, $\mathrm{M}_{2}$. Then water was poured in the flask over the Saltstone up to the mark and the flask was weighed again, $M_{3}$. The mass of Saltstone, $M_{s}$, is $M_{2}-M_{1}$. The mass of water in the flask is $M_{3}-M_{2}$. The volume of water in the flask, $V_{w}$, is $M_{3}-M_{2} / \rho_{w}$. The volume of Saltstone, $V_{S}$, is $100 \mathrm{~mL}-V_{W}$. The density of Saltstone, $\rho_{S}$, is $M_{S} / V_{S}$. The measured density for Saltstone was $1.76 \pm 0.01 \mathrm{~g} / \mathrm{cm}^{3}$. For comparison, the density of concrete is about $2.3 \mathrm{~g} / \mathrm{cm}^{3}$ [Kreith]. Saltstone has a lower density than concrete because it contains more water, a relatively low density material.

\section{MEASUREMENT OF SALTSTONE SPECIFIC HEAT}

The Saltstone specific heat was measured on June 27, 1997. A quantity of cured Reference Saltstone was crushed. The Saltstone was weighed and allowed to equilibrate at room temperature, which was measured. A dewar was weighed. A thermocouple was passed through a hole in the stopper for the dewar. A quantity of ethylene glycol was brought to about $100^{\circ} \mathrm{C}$ then poured into the dewar. The dewar with ethylene glycol was weighed, the stopper with thermocouple was inserted and its reading was monitored until it equilibrated. Then the stopper was raised momentarily, Saltstone was poured in and the stopper replaced. Again temperature was monitored until it equilibrated. Three runs were made. Figure 1 shows one of the temperature transients. The following equation was used to calculate the specific heat for Reference Saltstone

$$
C_{s}=\frac{M_{g} C_{g}\left(T_{m}-T_{g}\right)}{M_{s}\left(T_{s}-T_{m}\right)}
$$

where $C_{s}, C_{g}, M_{s}, M_{g}, T_{s}, T_{g}$ and $T_{m}$ are the specific heat of Saltstone, the specific heat of ethylene glycol, the mass of Saltstone, the mass of glycol, the initial temperature of the Saltstone, the initial temperature of the glycol and the mixed temperature. The result for specific heat was $0.304 \pm 0.01 \mathrm{cal} / \mathrm{g}^{\circ} \mathrm{C}$. For comparison, the specific heat of concrete is about $0.2 \mathrm{cal} / \mathrm{g}^{\circ} \mathrm{C}$ [Kreith]. Saltstone has a higher specific heat than concrete because it contains more water, which has a high specific heat.

\section{MEASUREMENT OF HEAT OF HYDRATION}

\subsection{Description of Adiabatic Calorimeter}

Heat of hydration of curing Saltstone was measured using a calorimeter. There are two types of calorimeter, isothermal and adiabatic. In an isothermal calorimeter the sample is held at constant temperature and heat generated in the sample is measured as it crosses the boundary of the sample. In an adiabatic calorimeter the sample container is immersed in a stirred bath. The bath temperature is controlled by an electric heater to be at the same temperature as the sample. By careful temperature matching the heat gain or loss from the sample can be made very small. The heat generation rate inside the sample dewar is obtained by multiplying the rate of temperature increase for the sample by the sum of the products of mass and specific heat for the sample and the inside of the sample dewar. The choice of isothermal or adiabatic calorimeter depends partly on the application of the data. An adiabatic calorimeter was chosen for the present measurement because heat transfer for design basis Saltstone pour rates is expected to be approximately adiabatic with large increases in temperature. A limitation of the present adiabatic calorimeter is that the bath can be heated quickly by the electric heater or can cool slowly because of heat losses from the outer dewar. Any mechanism that causes the sample to cool faster than the slow 
cooling of the ethylene glycol bath will cause a temperature mismatch between the sample and the bath for a period of time.

A schematic of the adiabatic calorimeter is shown in Figure 2. The Bollinger [1996] calorimeter was reused with some improvements; a more thorough thermocouple calibration, an uninterruptible power supply, an emergency shutdown circuit and more sophisticated hardware and software for temperature control. The freshly mixed Saltstone sample was poured in the one liter Sample Dewar which was sealed with a rubber stopper. Two thermocouples penetrated the rubber stopper, one of which measured the sample temperature and the other formed half of a differential thermocouple. The Inverted Dewar covered the Sample Dewar to further reduce heat losses and to provide an air pocket that helps to exclude ethylene glycol from the Sample Dewar. A stiff screen was placed in bottom of the Bath Dewar and the Sample Dewar was placed on top of the screen to allow the bath to circulate on all sides of the sample. Steel flanges were placed on top of the Sample Dewar to prevent it from floating. The Bath Dewar has a capacity of 25 liters and was filled with ethylene glycol which has a boiling point of $200^{\circ} \mathrm{C}$. A stirrer, a 1000 watt capacity electrical immersion heater and three thermocouples were immersed in the bath, one of which was the other half of the differential thermocouple. The intention of the temperature control was to make the differential temperature very close to zero. The stirrer was turned slowly so that frictional heating would not be significant. An insulated lid was placed over the top of the Bath Dewar to reduce heat loss.

\subsection{Calorimeter Instrumentation, Data Acquisition and Control}

The bath contained three Type $T$ thermocouples and one Type E thermocouple. Thermocouple TR-3522 was connected to the Primary Shutdown circuit which was part of the data acquisition system (DAS). This circuit shut off power to the heater when the temperature exceeded the set point, usually $120^{\circ} \mathrm{C}$, and could only be reset manually. The one Type E thermocouple, TR1861, was connected to the Secondary Shutdown Circuit which was independent of the DAS. Thermocouple TR-3521 measured the bath temperature and was connected to the DAS. Half of the differential thermocouple, TR-3524, was also immersed in the bath. The temperature of the sample was read by Type T thermocouple TR-3523. The other half of the differential thermocouple was also in the sample near TR-3523.

The differential thermocouple was the most important instrument used in the calorimeter. It consists of two ordinary Type $T$ thermocouples connected so that the voltages produced oppose each other. A differential thermocouple allows more accurate measurement of a temperature difference than separate measurement of two temperatures followed by digital subtraction. For an ideal differential thermocouple the output voltage is exactly zero for zero temperature difference. However, a real differential thermocouple exhibits a small voltage for zero temperature difference. The differential thermocouple was calibrated by immersing the two thermocouple tips adjacent to each other in a stirred bath maintained over a range of temperatures from $23^{\circ} \mathrm{C}$ to $130^{\circ} \mathrm{C}$. The results of the calibration, shown in Figure 3, allowed the output of the differential thermocouple to be corrected as a function of Saltstone temperature. Equation 2 is the result of the initial differential thermocouple calibration. Equation 3 is the result of a subsequent, more thorough calibration.

$$
\Delta \mathrm{mV}_{\text {cor }}=\Delta \mathrm{mV}_{\text {raw }}-0.004+0.001552 * \mathrm{mV}_{\mathrm{S}}
$$

$\Delta \mathrm{mV}_{\text {cor }}=\Delta \mathrm{mV}_{\text {raw }}-\left(0.0017058-0.00009059 * \mathrm{mV}_{\mathrm{S}}-0.00009606 * \mathrm{mV}_{\mathrm{S}}{ }^{2}\right)$

The terms $\Delta \mathrm{mV}_{\text {cor }}, \Delta \mathrm{mV}_{\text {raw }}$ and $\mathrm{mV}_{\mathrm{S}}$ were the corrected and uncorrected millivolt signals from the differential thermocouple and the millivolt signal from the ordinary thermocouple in the sample dewar, respectively. 
Figure 4 shows the connection of the thermocouples, DAS and control circuit. Temperature control for the calorimeter was accomplished by the DAS and the control circuit. The output of the differential thermocouple was connected to Multimeter and then to the DAS, which converted the voltage to digital form. The Bath Thermocouple and the Sample Thermocouple were connected to an Ice Point Reference, then to the Multimeter and finally to the DAS. Initially, calibration equation 2 , then later equation 3 , were used in the DAS to compute the corrected voltage output of the differential thermocouple which was used as the input for proportional and integral control equation. Initially, a simple proportional control equation was tried. However, on average it always produced a small offset in which the bath temperature was less than the sample temperature so an integral term was added. Trial and error were used to determine constants for the proportional and integral control. As a result, the following equation was programmed into the DAS for the control signal, $S$.

$$
\mathrm{S}=4.0+100 \Delta \mathrm{mV}_{\text {cor }}+0.25 \int \Delta \mathrm{mV}_{\text {cor }} \mathrm{dt}
$$

$S$ was constrained to be between 4 and 20 . An output channel of the DAS was used to generate a milliamp signal having a magnitude equal to $S$. This milliamp signal was connected to a pulse control module, Omega model PCM-1, in the Power Control Circuit. The pulse control module converts a 4-20 mA input to a time proportional square wave output. The module output is turned on $0 \%$ of the time for a $4 \mathrm{~mA}$ input and increases linearly to being on $100 \%$ of the time for a $20 \mathrm{~mA}$ input. The module output was connected to the input of a solid state relay (SSR), Omega model SSR 240DC45. The SSR allowed 110 VAC power to pass to the heater when the input of the SSR was energized.

Two shutdown circuits, shown in Figure 4, prevented the ethylene glycol from overheating. The Primary Shutdown Circuit received its input from the DAS. If the DAS measured a bath temperature greater than a set point temperature the associated analog output of the DAS changed from zero volts to 5 volts. The set point temperature was initially set at $100^{\circ} \mathrm{C}$, then increased to $120^{\circ} \mathrm{C}$. Exceeding the set point caused a mechanical relay to open so that no power could reach the bath heater. An independent shutdown circuit was added because it is remotely possible for the DAS computer lock up in the mode that power was being supplied continuously to the ethylene glycol bath. An additional Type E thermocouple was connected to a Omega model CN4400TR-A temperature controller. The output of the temperature controller was connected to a solid state relay which could interrupt electrical power to the bath heater. The Independent Shutdown Circuit had a higher set point than the Primary Shutdown Circuit and so was never called upon during the period that the calorimeter was operated.

Figure 5 shows data that illustrate the operation of the Power Control Circuit at the most demanding time, at the beginning of the run. The Sample Dewar was filled with fresh Saltstone, closed and immersed in the bath at time zero. Initially there was a negative temperature difference with the Saltstone being $4^{\circ} \mathrm{C}$ cooler than the bath so no heat was added to the bath. The initial low heat of hydration slowly warmed the Saltstone and after 11 hours the temperature difference and the proportional term in equation 3 became positive. However, the integral term in equation 3 was still significantly negative. The signal, $S$, would have been less than 4.0 but was constrained to be no less than 4.0 and no power was applied to the heater. At 12.8 hours the signal became positive and the heater was briefly energized to a peak power of 780 watts. Thereafter, the heater power never exceeded 10 watts and the Saltstone and bath temperatures tracked each other closely. The apparent temperature difference between the bath and sample shown in the figure is the result of imperfect calibration of the Saltstone and bath thermocouples. The actual average directly measured differential temperature from 16 hours to 124 hours was quite small, $-0.002^{\circ} \mathrm{C}$. The maximum instantaneous temperature variation was $\pm 0.36^{\circ} \mathrm{C}$. 


\subsection{Shakedown Testing}

Details of all testing are recorded in a laboratory notebook, WSRC-NB-97-29. Two types of shakedown tests were performed, a heatup test with a known electrical power and a drift test with no heat generation. On May 3, 1997 a Resistance Temperature Device (RTD) was placed in the Test Vessel Dewar as a heat source along with $511.7 \mathrm{~g}$ of ethylene glycol. Equation 1 was used for the differential thermocouple calibration. An electrical power of $29.9 \mathrm{~mW}$ was supplied to the RTD. The power was measured by separately measuring the voltage across the RTD and the current supplied to it. The temperature increased from $75.4^{\circ} \mathrm{C}$ to $84.3^{\circ} \mathrm{C}$ in period of 135 hours which corresponds to a rate of $0.0659 \mathrm{~K} / \mathrm{hr}$.

Assuming no heat losses from or gains by the Sample Dewar the relationship between heat generation rate, $\mathrm{G}$, and temperature follows. The terms $\mathrm{M}_{\mathrm{i}}$ and $\mathrm{C}_{\mathrm{pi}}$ are the mass and specific heat of component $i$, respectively. The summation gives the total thermal capacity for the calorimeter.

$$
\mathrm{G}=\frac{\mathrm{dT}}{\mathrm{dt}} \sum_{\mathrm{i}=1}^{\mathrm{n}} \mathrm{M}_{\mathrm{i}} \mathrm{C}_{\mathrm{p} i}
$$

Four components absorbed heat from the RTD; the ethylene glycol, the inner surface of the dewar, part of the rubber stopper and the RTD. The inner surface of the dewar was assumed to have half of the total mass of the dewar. The affected part of the rubber stopper was assumed to have half of the total stopper mass.

Table 1 Data for RTD Heatup Test

\begin{tabular}{lccc} 
component & $\mathrm{M}, \mathrm{g}$ & $\mathrm{C}_{\mathrm{p}}, \mathrm{cal} / \mathrm{g} \mathrm{K}$ & $\mathrm{M} \mathrm{C}_{\mathrm{p}} \mathrm{cal} / \mathrm{K}$ \\
\hline ethylene glycol & 511.7 & 0.655 & 335.2 \\
half of dewar & 246.4 & 0.20 & 49.3 \\
RTD & 23.9 & 0.20 & 4.8 \\
half of stopper & 42.2 & 0.48 & 20.3 \\
total & & & 409.6
\end{tabular}

The specific heat of ethylene glycol was taken from the Handbook of Chemistry and Physics. For the purpose of estimating specific heat, the dewar, RTD and stopper were assumed to be made of glass, glass and rubber, respectively. Specific heats were found in Kreith.

Rearranging equation 5 shows that the predicted heatup rate is equal to the applied electrical power divided by the total $\mathrm{MC}_{\mathrm{p}}$ product. Using consistent units the predicted heatup rate is $0.0628 \mathrm{~K} / \mathrm{hr}$ which is $4.3 \%$ less than the actual measured heatup rate.

An uncertainty analysis was performed on the calorimeter, partially to determine if the $4.3 \%$ difference has the expected magnitude. Inspecting equation 5, the significant factors that contributed to uncertainty in measured heat generation are uncertainty in temperature increase, uncertainties in some specific heats and uncertainties in effective masses of the dewar and the rubber stopper. The uncertainty in the initial and final temperatures is $\pm 0.3^{\circ} \mathrm{C}$. Using the root sum square relationship the uncertainty in the temperature increase is $\pm 0.42^{\circ}$ or $4.7 \%$ of the total temperature increase, the biggest contributor to overall uncertainty. The specific heat of the stopper could be in error by $20 \%$ or change in $\mathrm{MC}_{\mathrm{p}}$ of 2.0. The specific heat of the RTD could be in error by $40 \%$ or a change in $M C_{p}$ of 1.9. The mass of the inner half of the dewar could be in error by $10 \%$ or a change in $M_{\mathrm{P}}$ of 4.9 . The effective mass of part of the stopper could be in error by $100 \%$ or a change in $M C_{p}$ of 10.0 . Employing root sum square the overall uncertainty in $\mathrm{MC}_{\mathrm{p}}$ is 11.5 out of 409.6 or $2.8 \%$. Using root sum square to combine the uncertainty in $\mathrm{M}$ of $2.8 \%$ with the uncertainty of $4.7 \%$ in the temperature increase gives an 
overall uncertainty of $5.5 \%$ in measured heatup rate. Therefore, the discrepancy between measured and predicted heatup rates is somewhat less than the uncertainty in $\mathrm{MC}_{\mathrm{p}}$ of the Test Vessel Dewar and its contents.

The second shakedown test was a drift test with no heat generation inside the Sample Dewar. On June 19, 1997 the Test Vessel Dewar was filled with ethylene glycol at $112^{\circ} \mathrm{C}$ and zero heat load. The improved differential thermocouple calibration equation, Equation 3, was used. Over a period of 86 hours the average rate of drift was only $+0.0006 \mathrm{~K} / \mathrm{hr}$, which is excellent. There was an earlier drift test on June 16 at 16:54. The temperature controller was inadvertently turned off for the first four hours of the run. However, data from this run were used to calculate the temperature drift of the Sample Dewar when there was a significant temperature difference between the Sample Dewar and the bath. The drift was $0.2^{\circ} \mathrm{C} / \mathrm{hr}$ drift for each degree of temperature difference.

\subsection{Saltstone Calorimeter Runs}

Two calorimeter runs were performed with freshly mixed Saltstone in the Sample Dewar. The compositions of Low Cement Saltstone and Reference Saltstone are listed Table 2.

\section{Table 2 Saltstone Formulations}

Salt solution used for both calorimeter runs

\begin{tabular}{lc} 
component & wt \% \\
\hline $\mathrm{H}_{2} \mathrm{O}$ & 71.0 \\
$\mathrm{NaNO}_{3}$ & 14.0 \\
$\mathrm{NaNO}_{2}$ & 3.5 \\
$\mathrm{NaOH}$ & 3.8 \\
$\mathrm{Na}_{2} \mathrm{CO}_{3}$ & 1.5 \\
$\left.\mathrm{NaAl}_{3} \mathrm{OH}\right)_{4}$ & 3.3 \\
$\mathrm{Na}_{2} \mathrm{SO}_{4}$ & 1.7 \\
$\mathrm{NaCl}$ & 0.11 \\
$\mathrm{Na}_{2} \mathrm{C}_{2} \mathrm{O}_{4}$ & 0.28 \\
$\mathrm{Na}_{3} \mathrm{PO}_{4}$ & 0.12
\end{tabular}

Low Cement Test Mix

\begin{tabular}{lr} 
component & wt \% \\
\hline Salt solution & 44.0 \\
Portland cement & 3.4 \\
slag & 26.3 \\
flyash & 26.3
\end{tabular}

Reference Saltstone Test Mix

\begin{tabular}{lc} 
component & wt \% \\
\hline salt solution & 46.0 \\
Portland cement & 6.0 \\
slag & 24.0 \\
flyash & 24.0
\end{tabular}

The first run started May 16, 1997, ended on May 27 and used Low Cement Saltstone. Unfortunately, the last half of the data record for the Low Cement Saltstone was lost after lighting caused a power failure that locked up the DAS. Although the DAS was connected to an uninterruptible power supply (UPS), the DAS was attempting to communicate with a voltmeter that was not connected to a UPS. This situation was corrected for the second run. The temperature record for the Low Cement Saltstone run is shown in Figure 6. The Saltstone temperature was initially $41^{\circ} \mathrm{C}$ and increased only slightly until 10 hours when there was a large increase for a period of 8 hours. There was an initial temperature mismatch with the bath $2^{\circ} \mathrm{C}$ 
hotter than the Saltstone. After 18 hours the temperature increased more slowly until 115 hours, after which the data were lost.

The second run was with Reference Saltstone which started on June 25, 1997 and ended on August 4, a period of 880 hours. The temperature record is shown in Figure 6 (up to 160 hours) and Figure 7. Figure 6 shows that the Reference Saltstone generated somewhat less heat than the Low Cement Saltstone. The 1995 Bollinger test generated even less heat. The reason may have been freshness of ingredients. The freshest ingredients were used in the Low Cement Saltstone test. Ingredients for the Reference Saltstone test were less fresh. Bollinger may have been given relatively old ingredients for his 1995 calorimeter run. A calorimeter run for Hanford grout (PNL-7979) is also listed with a temperature record that fell between the Reference Saltstone Run and the Bollinger Run.

The complete temperature record for the Reference Saltstone Run is plotted in Figure 7. The Saltstone temperature was initially $37^{\circ} \mathrm{C}$ and increased only slightly until 11 hours when there was a large increase for a period of 11 hours. There was an initial temperature mismatch with the bath $3^{\circ} \mathrm{C}$ hotter than the Saltstone. After 180 hours the Saltstone reached a temperature of $110^{\circ} \mathrm{C}$. The vapor pressure of water at that temperature is about $6 \mathrm{psig}$. The rubber stopper popped up and released steam. This process removed heat and thus for a period of days the calorimeter was not adiabatic. After 340 hours the stopper was manually reseated and the temperature of the Saltstone again increased. The rubber stopper blew out again after 460 hours when the temperature was $108^{\circ} \mathrm{C}$. The stopper was reseated after 530 hours. After 600 hours the temperature of the bath and the sample dewar were intentionally decreased to avoid blowing out the stopper again. After 840 hours the temperature was intentionally reduced to determine if this would reduce the heat of hydration. However, at this point the measured rate of temperature rise, $0.0025 \mathrm{~K} / \mathrm{hr}$, was only four times as large as the adiabatic drift rate reported in Section 4.3, $0.0006 \mathrm{~K} / \mathrm{hr}$. Therefore, the decision was made to stop data collection. Note that the final temperature reached by the Saltstone in Figure 7 was less than it would have been if the stopper had not blown out twice and the temperature intentionally reduced once. However, the slope of the temperature plot is correct with the exception of those periods.

\subsection{Analysis of Saltstone Calorimeter Data}

For the Low Cement Saltstone run and the Reference Saltstone run the Saltstone temperature drifted upward for the first 10 hours and 11 hours, respectively, because the bath was hotter than the Sample Dewar. The amount of temperature drift observed corresponds to the amount of drift expected for the temperature mismatch between the sample and bath. Therefore, there was no actual heat of hydration for the initial periods.

Equation 5 allows the calculation of heat of hydration for times beyond the initial periods. That equation requires the sum of the products of mass and specific heat for the two runs which is listed in the following tables.

Table 3 Data for Low Cement Saltstone Test

\begin{tabular}{lrcc} 
component & $\mathrm{M}, \mathrm{g}$ & $\mathrm{C}_{\mathrm{p}}, \mathrm{cal} / \mathrm{g} \mathrm{K}$ & $\mathrm{MC}, \mathrm{cal} / \mathrm{K}$ \\
\hline Saltstone & 674.3 & 0.304 & 205.0 \\
half of dewar & 246.4 & 0.20 & 49.3 \\
cloth liner & 3.7 & 0.50 & 1.8 \\
plastic liner & 3.7 & 0.50 & 1.8 \\
half of stopper & 42.2 & 0.48 & 20.3
\end{tabular}

total

278.2 
Table 4 Data for Reference Saltstone Test

\begin{tabular}{lrlr} 
component & $\mathrm{M}, \mathrm{g}$ & $\mathrm{C}_{\mathrm{p}}, \mathrm{cal} / \mathrm{g} \mathrm{K}$ & $\mathrm{M} \mathrm{C}_{\mathrm{p}} \mathrm{cal} / \mathrm{K}$ \\
\hline Reference Saltstone & 696.5 & 0.304 & 211.7 \\
half of dewar & 246.4 & 0.20 & 49.3 \\
cloth liner & 3.7 & 0.50 & 1.8 \\
plastic liner & 3.7 & 0.50 & 1.8 \\
half of stopper & 42.2 & 0.48 & 20.3 \\
total & & & 284.9
\end{tabular}

Evaluation of equation 5 also requires the first derivative of temperature. L. L. Hamm used Cubic Spline Interpolation [Press, et al.] to calculate the first derivative of both data sets. Cubic Spline Interpolation is described by the following five equations.

$$
\begin{aligned}
& y=A y_{j}+B y_{j+1}+C y_{j} "+D y_{j+1} " \\
& A=\left(x_{j+1}-x\right) /\left(x_{j+1}-x_{j}\right) \\
& B=1-A \\
& C=1 / 6\left(A^{3}-A\right)\left(x_{j+1}-x_{j}\right)^{2} \\
& D=1 / 6\left(B^{3}-B\right)\left(x_{j+1}-x_{j}\right)^{2} \\
& \frac{d y}{d x}=\frac{y_{j+1}-y_{j}}{x_{j+1}-x_{j}}-\frac{3 A^{2}-1}{6}\left(x_{j+1}-x_{j}\right) y_{j},+\frac{3 B^{2}-1}{6}\left(x_{j+1}-x_{j}\right) y_{j+1},
\end{aligned}
$$

The Cubic Spline Interpolation method requires that knots be selected to divide the temperature record into segments. The $x_{j}$ and $y_{j}$ coordinates (time and temperature) for the knots are listed below. The method calculates second derivatives of temperature at the knots, $\mathrm{y}^{\prime \prime}$, which are also listed below. Equations 6 through 10 are used to generate the interpolation of the temperature record for all times. Equations 7, 8 and 11 are used to generate the first derivative of temperature for all times.

\section{Table 5}

$\begin{array}{lccc}\begin{array}{l}\text { Cubic } \\ \text { knot }\end{array} & \begin{array}{c}\text { Spline } \\ \mathrm{x} \\ \text { time, hr. }\end{array} & \begin{array}{c}\text { Interpolation for } \\ \mathrm{y} \\ \text { temperature, }{ }^{\circ} \mathrm{C}\end{array} & \begin{array}{l}\text { Low Cement Saltstone Calorimeter Run } \\ \mathrm{y}^{\prime \prime} \\ \text { second derivative } \\ \text { of temperature }\end{array} \\ 1 & 10 & 45.047 & 0.83040 \\ 2 & 11 & 48.649 & 11.49902 \\ 3 & 12 & 58.644 & -8.46483 \\ 4 & 14 & 66.190 & 0.97811 \\ 5 & 17 & 72.786 & -0.76644 \\ 6 & 20 & 76.143 & -0.07101 \\ 7 & 28 & 79.848 & -0.00925 \\ 8 & 44 & 84.379 & -0.00424 \\ 9 & 77 & 90.852 & 0.00127 \\ 10 & 114 & 98.341 & 0.00000\end{array}$


Note: heat of hydration is zero for times less than 10 hours.

$\begin{array}{lccc}\begin{array}{l}\text { Table } \\ \text { Cubic } \\ \text { knot }\end{array} & \begin{array}{l}\text { Spline } \\ \mathrm{x}\end{array} \\ \text { time, hr. } & \begin{array}{c}\text { Interpolation for } \\ \mathrm{y} \text { temperature, }{ }^{\circ} \mathrm{C}\end{array} & \begin{array}{c}\text { Reference Saltstone Calorimeter Run } \\ \mathbf{y}^{\prime \prime} \\ \text { second derivative } \\ \text { of temperature }\end{array} \\ 1 & 11 & 43.162 & 0.30987 \\ 2 & 12 & 45.768 & 7.55420 \\ 3 & 13.5 & 57.079 & -5.64832 \\ 4 & 15.6 & 62.891 & 0.33285 \\ 5 & 20 & 68.900 & -0.19956 \\ 6 & 28 & 74.935 & -0.02281 \\ 7 & 44 & 79.775 & -0.00128 \\ 8 & 100 & 91.989 & 0.00076 \\ 9 & 160 & 105.296 & -0.00138 \\ 10 & 180 & 108.766 & -0.00575 \\ 11 & 191 & 109.971 & 0.00000\end{array}$

Note: heat of hydration is zero for times less than 11 hours.

The temperature record for the Reference Saltstone was discontinuous and some data segments could not be used for determining heat of hydration because the rubber stopper had popped up. The Cubic Spline Method could not be used for times beyond 191 hours. Therefore, fourth order polynomial curve fits are listed below for the four usable segments of the temperature record for times greater than 191 . Temperature and the first derivative of temperature were evaluated using the following equations where $\mathrm{T}$ and $\mathrm{t}$ have units of ${ }^{\circ} \mathrm{C}$ and hours, respectively.

$$
\begin{aligned}
& T=C_{0}+C_{1} t+C_{2} t^{2}+C_{3} t^{3}+C_{4} t^{4} \\
& d T / d t=C_{1}+2 C_{2} t+3 C_{3} t^{2}+4 C_{4} t^{3}
\end{aligned}
$$

Table 7 Fourth Order Curve Fits for Reference Saltstone

$\begin{array}{llrrrcc}\begin{array}{l}\text { start } \\ \text { time, } \\ \text { hours }\end{array} & \begin{array}{l}\text { stop } \\ \text { time, } \\ \text { hours }\end{array} & \mathrm{C}_{0} & \mathrm{C}_{1} & \mathrm{C}_{2} & \mathrm{C}_{3} & \mathrm{C}_{4} \\ & & & & & & \\ 350 & 485 & -78.718 & 1.724 & -6.360 \mathrm{E}-3 & 1.072 \mathrm{E}-5 & -6.793 \mathrm{E}-9 \\ 530 & 575 & 76.653 & 0.077 & -4.948 \mathrm{E}-5 & 0.000 \mathrm{E}+0 & 0.000 \mathrm{E}+0 \\ 625 & 780 & 144.138 & -0.301 & 6.867 \mathrm{E}-4 & -6.567 \mathrm{E}-7 & 2.284 \mathrm{E}-10 \\ 900 & 960 & 7771.971 & -33.062 & 5.324 \mathrm{E}-2 & -3.809 \mathrm{E}-5 & 1.022 \mathrm{E}-8\end{array}$

Equation 5 was rewritten as follows for the heat of hydration for the Low Cement Saltstone run, where $Q_{\text {hyd }}, \mathrm{T}$ and t have units of watts $/ \mathrm{kg}$, ${ }^{\circ} \mathrm{C}$ and hours, respectively.

$$
\mathrm{Q}_{\text {hyd }}=\frac{278.2 \mathrm{cal} / \mathrm{C}}{0.6743 \mathrm{~kg}} \frac{\mathrm{dT}}{\mathrm{dt}} \frac{\mathrm{hr}}{3600 \mathrm{~s}} \frac{4.186 \text { watt } \mathrm{s}}{\mathrm{cal}}=0.480 \frac{\mathrm{dT}}{\mathrm{dt}}
$$


The constant of proportionality for the Reference Saltstone run was slightly different, 0.475 . Equations 6 through 14 and the data in Table 5 through 7 were used to calculate the heats of hydration, plotted for Low Cement Saltstone and Reference Saltstone in Figures 8, 9 and 10. In both cases the heat of hydration reached a peak of about $6 \mathrm{~W} / \mathrm{kg}$ at 12 hours decreasing to about $0.15 \mathrm{~W} / \mathrm{kg}$ at 25 hours. After 25 hours the heat of hydration for Reference Saltstone has a semilogarithmic form with the following equation.

$$
\log _{10}\left(Q_{\text {hyd }}\right)=-0.766-0.00232 \mathrm{t}
$$

The sinusoidal appearance of the heat of hydration for some data segments in Figure 10 is an artifact of the method of curve fitting.

An uncertainty analysis was performed for the Low Cement Saltstone Test. With the exception of the curve fitting process the major sources of uncertainty were the specific heat of the stopper, the effective mass of the dewar, the effective mass of the stopper and the specific heat of the Saltstone. From before, the first three terms contributed to uncertainty in $\mathrm{M} \mathrm{C}_{\mathrm{p}}$ in the amounts of $2.0,4.9$. and $10.0 \mathrm{cal} / \mathrm{K}$. Using the previously stated uncertainty of Saltstone specific heat the contribution to uncertainty in $\mathrm{M} \mathrm{C}_{\mathrm{p}}$ is $6.7 \mathrm{cal} / \mathrm{K}$. The root sum square of the four contributions is $13.1 \mathrm{cal} / \mathrm{K}$ or $4.7 \%$. The contribution to overall uncertainty of heat of hydration from imperfect curve fits is difficult to estimate. On average, this contribution is zero but over short periods of time can be much larger.

\section{MEASUREMENT OF THERMAL CONDUCTIVITY}

\subsection{Cylindrical Geometry}

Two methods were used to measure thermal conductivity, steady conduction in a cylindrical geometry and transient conduction in a spherical geometry. Figure 11 shows the cylindrical test piece. The central heat source was a Watlow Firerod 9732 0.25" diameter rod heater 24 " long. Before installation into the test piece the rod heater was tested to determine its heated length by rubbing paraffin along the length of the heater. A low power level was applied to the heater and it was observed that the paraffin melted along a length, L, of 20.3". The paraffin was cleaned from the heater and four type $\mathrm{J}$ thermocouples were attached to the heater at $90^{\circ}$ intervals at the middle of the heated zone so that their centerlines were a nominal 0.14 " from the surface of the heater. This corresponds to a nominal radius from the centerline of the test piece of $0.265^{\text {". }}$. The heater was then centered in a 2" aluminum pipe having an inside diameter of 2.067 inches or a radius of 1.033". Four other type J thermocouples were peened into grooves cut into the outside surface of the aluminum pipe. Freshly mixed Reference Saltstone was poured into the aluminum pipe and allowed to cure for two weeks so that the heat of hydration was negligible with respect to the heat generation of the heater. Fiberglass insulation was pressed into the pipe above and below the Saltstone. The aluminum pipe was then centered in a 4" PVC pipe. A thermocouple was placed in the PVC pipe at the top and another at the bottom. Process water flowing at $5 \mathrm{gpm}$ was introduced at the bottom of the PVC pipe and flowed past the outside of the aluminum pipe and out a drain at the top. The purpose of the cooling water was to establish a uniform boundary condition at the outer surface of the pipe. After cooling water flow was started on December 18, 1997 the heater was supplied with an electrical power of 99.64 watts. Power was measured by separately measuring voltage and current and multiplying the two quantities together.

Temperatures were monitored as shown in Figures 12 and 13. Steady state was achieved after an hour. The cooling water temperature drifted $0.3^{\circ} \mathrm{C}$ which caused the reading of the outer thermocouples to change by the same amount. This had a negligible effect on the measurement of thermal conductivity. The following equation was used to determine thermal conductivity [Kreith]. 


$$
\mathrm{k}=\frac{\mathrm{Q} \ln \frac{\mathrm{r}_{2}}{\mathrm{r}_{1}}}{2 \pi \mathrm{L}\left(\mathrm{T}_{1}-\mathrm{T}_{2}\right)}
$$

The thermal conductivity of the aluminum pipe was two orders larger than the Saltstone so that the temperature drop across the aluminum to the outer thermocouples was negligible. At the conclusion of the test the test piece was cut open and the actual radii of the inner thermocouples and the inner surface of the aluminum pipe were measured with the following results for dimension and thermal conductivity. Temperatures listed are averages for the last hour of the run.

Table 8 Data and Results for Thermal Conductivity Test

$\begin{array}{cccrccc}\# & \mathrm{r}_{1}, \text { inches } & \mathrm{r}_{2} \text { inches } & \mathrm{T}_{1},{ }^{\circ} \mathrm{C} & \mathrm{T}_{2},{ }^{\circ} \mathrm{C} & \mathrm{k}, \mathrm{btu} / \mathrm{ft} \mathrm{hr}{ }^{\circ} \mathrm{F} & \mathrm{k}, \mathrm{W} / \mathrm{m} \mathrm{K} \\ 1 & 0.245 & 1.033 & 65.3 & 20.3 & 0.568 & 0.984 \\ 2 & 0.255 & 1.033 & 59.4 & 20.6 & 0.641 & 1.109 \\ 3 & 0.205 & 1.033 & 67.2 & 20.3 & 0.613 & 1.061 \\ 4 & 0.205 & 1.033 & 66.2 & 20.3 & 0.626 & 1.084\end{array}$

An uncertainty analysis was performed. The dominant factors causing uncertainty were uncertainties in the locations of the inner thermocouple beads and the measurement accuracy of the thermocouples. The overall $95 \%$ confidence level thermal conductivity was $0.61 \pm 0.04$ $\mathrm{btu} / \mathrm{ft} \mathrm{hr}{ }^{\circ} \mathrm{F}$ or $1.06 \pm 0.06 \mathrm{~W} / \mathrm{m} \mathrm{K}$.

\subsection{Spherical Geometry}

The second method used a spherical geometry. Saltstone was poured into a glass Christmas tree ornament having an outside diameter of $3.60^{\prime \prime}$ and a wall thickness of $0.02 "$. A thermocouple was pressed into the fresh Saltstone so that the location of its bead was at the center of the sphere. The Saltstone was allowed to cure for two weeks. The test was conducted by submerging the sphere in large beaker of boiling water while logging the temperature reading of its thermocouple. The results are shown in Figure 14. In Figure 15 the same data are normalized so that the initial and final normalized temperatures are zero and one, respectively. Thermal conductivity was determined from this temperature transient using a textbook [Rohsenow, et al.] calculation. Figure 16 shows the theoretical normalized temperature for the centerline of a sphere as a function of the term $\alpha \mathrm{t} / \mathrm{r}_{1}^{2}$ after exposure to a uniform convective environment at the surface of the sphere. The term $\alpha$ is the thermal diffusivity defined as $k / \rho C_{p}$. It is necessary to estimate the heat transfer coefficient from the boiling water to the sphere because the parameter for the curves is the Nusselt number based on radius, $\mathrm{h} \mathrm{r}_{1} / \mathrm{k}$. Figure 17 [Hetsroni] shows that the typical rise velocity for air bubbles in water is about $30 \mathrm{~cm} / \mathrm{sec}$ or 1.0 $\mathrm{ft} / \mathrm{sec}$. Steam bubbles in water would rise about as fast. The motion of the bubbles moves water around the beaker with a typical velocity of about $1.0 \mathrm{ft} / \mathrm{sec}$. This situation was approximated as a sphere suspended in water flowing at $1.0 \mathrm{ft} / \mathrm{sec}$. The Reynolds number based on sphere diameter is 100000 . From Kreith [1973] the corresponding Nusselt number based on diameter, $\mathrm{h} \mathrm{D} / \mathrm{k}$, is equal to 270 . The Nusselt number based on sphere radius is half of that or 135 . It is fortunate that the Nusselt number is so large because it means that the temperature transient is insensitive to the precise value of the Nusselt number. Tabular data for the curve for a Nusselt equal to 100 were extracted from Figure 16. Trial values of $\alpha$ were selected so that time, $t$, could be computed from the variable $\alpha \mathrm{t} / \mathrm{r}_{1}{ }^{2}$. Figure 15 shows that the best agreement between theory and measurement occurred when $\alpha$ was made equal to 0.0165 . Using the previously measured values of density and specific heat for Saltstone this corresponds to a thermal conductivity of $0.55 \mathrm{btu} / \mathrm{ft} \mathrm{hr}{ }^{\circ} \mathrm{F}$ or $0.95 \mathrm{~W} / \mathrm{m} \mathrm{K}$. No uncertainty analysis was performed, however, the 
spherical measurement is expected to be less certain than the cylindrical measurement. The two methods for measuring thermal conductivity differed by only $0.06 \mathrm{btu} / \mathrm{ft} \mathrm{hr}{ }^{\circ} \mathrm{F}$, which is comparable to the uncertainties of the measurements.

\section{CONCLUSIONS}

a. The measured density and specific heat for Reference Saltstone were $1.76 \pm 0.01 \mathrm{~g} / \mathrm{cm}^{3}$ and $0.304 \pm 0.01 \mathrm{cal} / \mathrm{g} \mathrm{K}$.

b. Shakedown testing showed that the adiabatic calorimeter was accurate and had a low rate of temperature drift.

c. The heats of hydration for the low cement Saltstone and the Reference Saltstone were similar even though the Low Cement Saltstone had half as much Portland cement. Apparently, heats of hydration of flyash and slag are about as large as the heat of hydration as Portland cement.

d. The heat of hydration for Reference Saltstone is large enough that the temperature inside a large monolith of curing Saltstone could easily exceed $100^{\circ} \mathrm{C}$.

e. Bollinger measured a heat of hydration that was about $65 \%$ as large as the presently measured heat of hydration for Reference Saltstone. The apparent reason for this was that Bollinger was given ingredients that were not fresh and therefore partially hydrated.

5. The thermal conductivity of Reference Saltstone measured with the more rigorous, steady conduction cylinder method is $1.06 \pm 0.06 \mathrm{~W} / \mathrm{m} \mathrm{K}$.

6. The simple transient sphere method for measuring thermal conductivity is less accurate than the steady conduction cylinder method but is much easier and so should be considered for future use.

\section{ACKNOWLEDGMENTS}

The calorimeter hardware was initially developed by J. S. Bollinger. V. L. Bush wired the instruments and the DAS. L. L. Hamm used Cubic Spline Interpolation to calculate the first derivatives of the temperature records collected using the adiabatic calorimeter.

\section{REFERENCES}

Bollinger, J. S., "Reference Saltstone Heat of Hydration Scoping Calorimetric Measurements", WSRC-TR-96-0103, April 1996.

Gad Hetsroni, Handbook of Multiphase Systems, p. 1-211, 1982.

Frank Kreith, Principles of Heat Transfer, Third Edition, p. 472, 1973.

R. O. Lokken, "Heat of Hydration of Double-Shell Slurry Feed Grouts", PNL-7860, December 1992.

R. O. Lokken, P. F. C. Martin and J. W. Shade, "Characterization of Double-Shell Slurry Feed Grout Produced in a Pilot Scale Test", PNL-7979, December 1992.

R. O. Lokken, "Heat of Hydration of Simulated 106-AN Grouts", PNL-7859, December 1992. 
R. O. Lokken, "Formulation Verification Study Results for Tank 106-AN Waste", PNL-7966, December 1992.

John H. Perry, Cecil H. Chilton and Sidney D. Kirkpatrick, Chemical Engineers' Handbook, Fourth Edition, 1963.

W. H. Press, B. P. Flannery, S. A. Teutolsky and W. T. Vetterling, Numerical Recipes, 1989.

Warren M. Rohsenow, James P. Hartnett and Ejup N. Ganic, Handbook of Heat Transfer Fundamentals, 1985.

Shadday, M. A., "Heat Transfer Modeling of the Saltstone Pouring and Curing Process", WSRC-TR-93-528, November 1993.

Shadday, M. A., "Saltstone Pour Thermal Modeling", SRT-EMS-960053, June 1996.

Shadday, M. A., "Thermal Modeling Results for the Saltstone Pouring and Curing Process", SRT-EMS-970004, January 1997. 
14

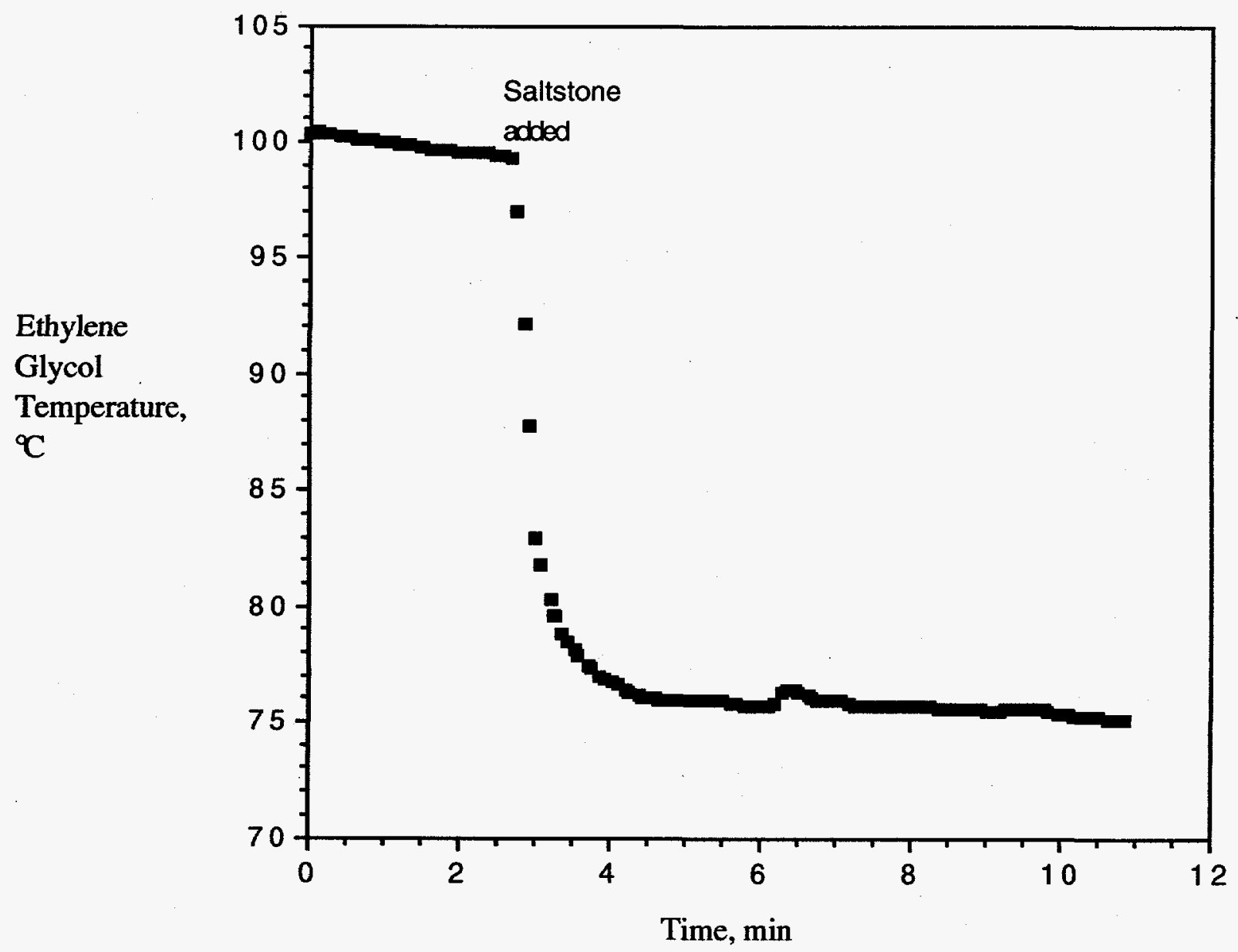

Figure 1

Temperature Record for Measurement of Specific Heat for Reference Saltstone 
bath TC,TR-3521

primary shutdown

TC, TR-3522

independent shutdown

TC, TR-1861

half of differential

thermocouple

TR-3524

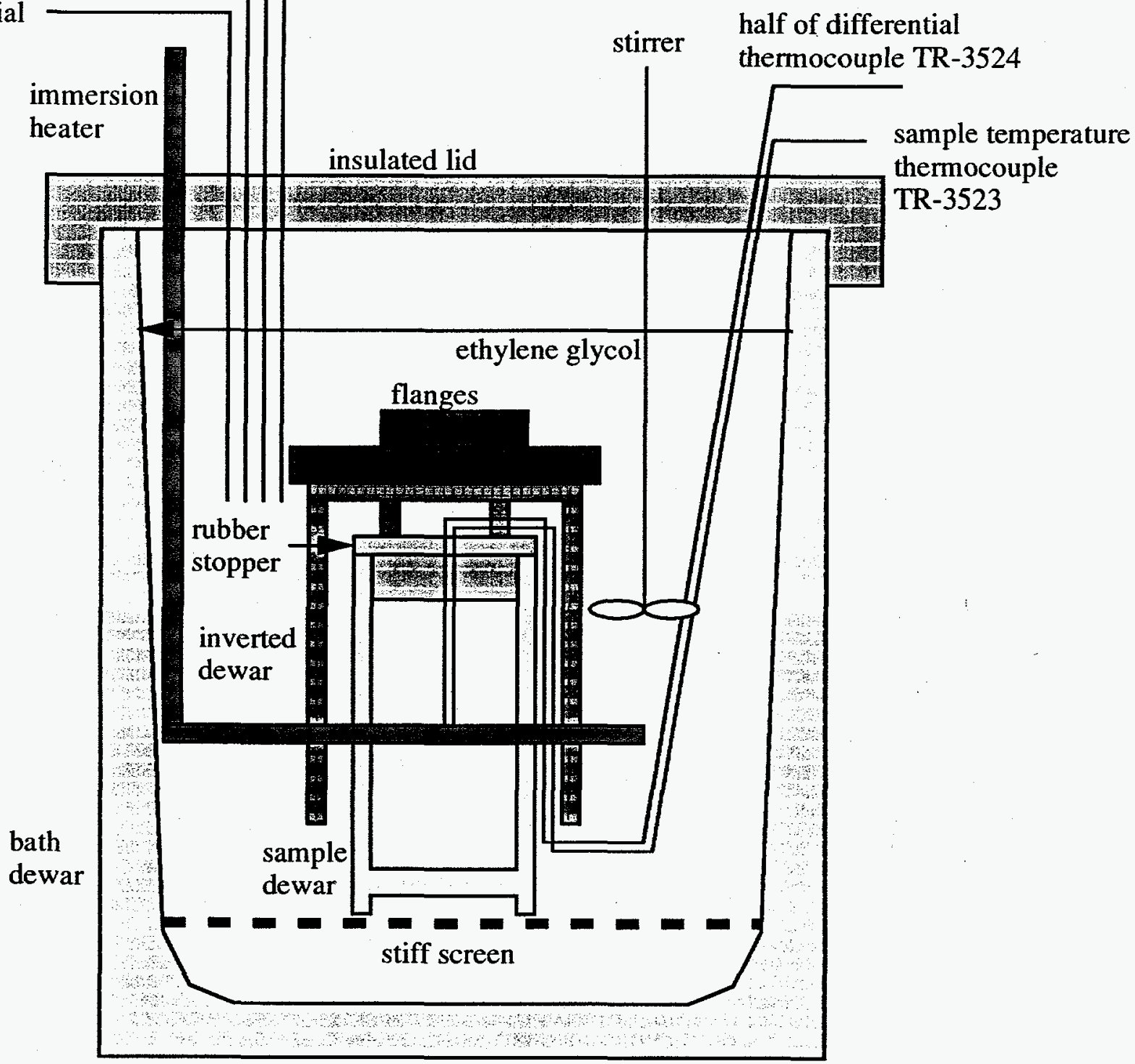

Figure 2 Adiabatic Calorimeter 


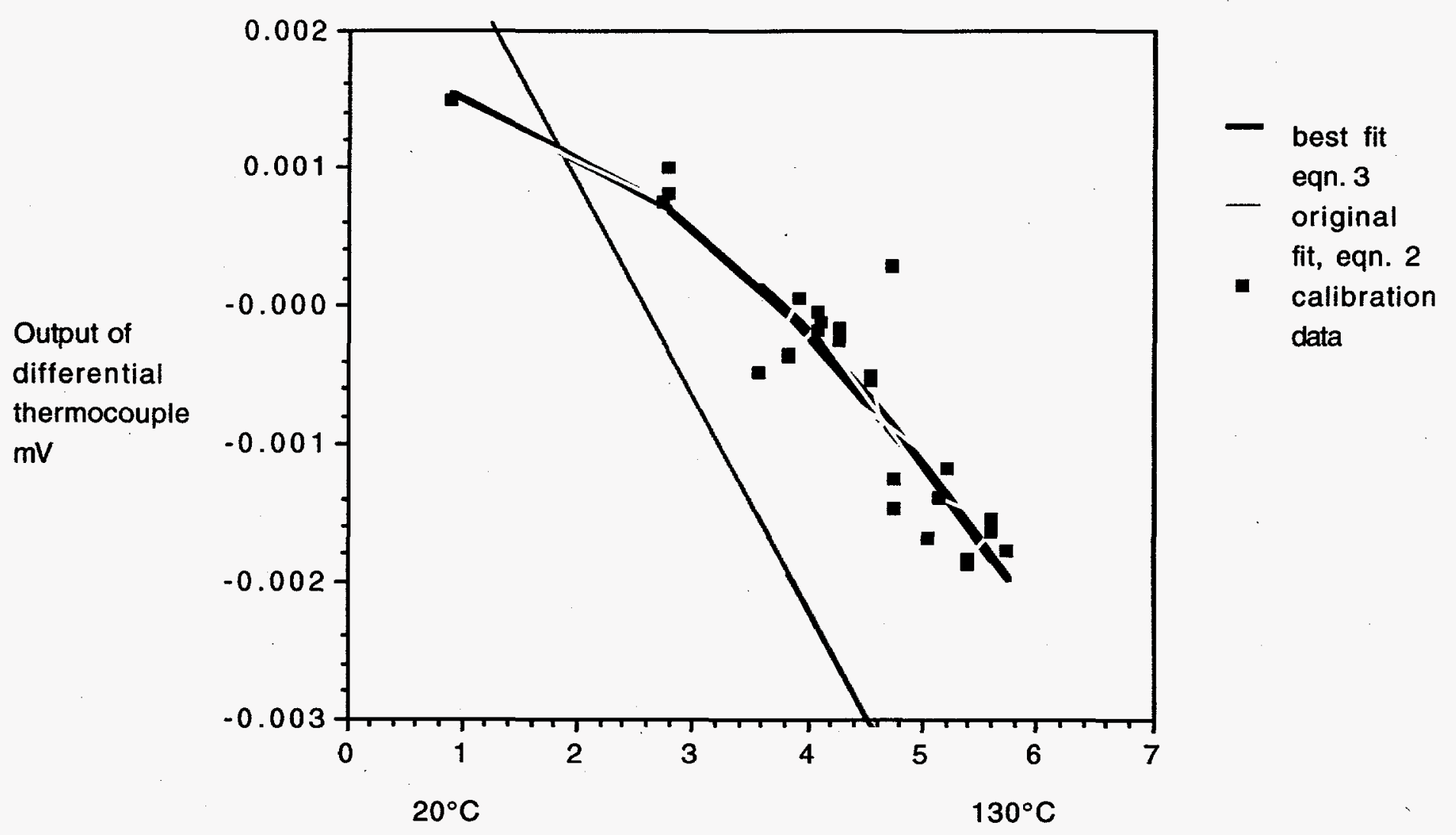

Output of sample thermocouple, $\mathrm{mV}$

Figure 3

Calibration of Differential Thermocouple 


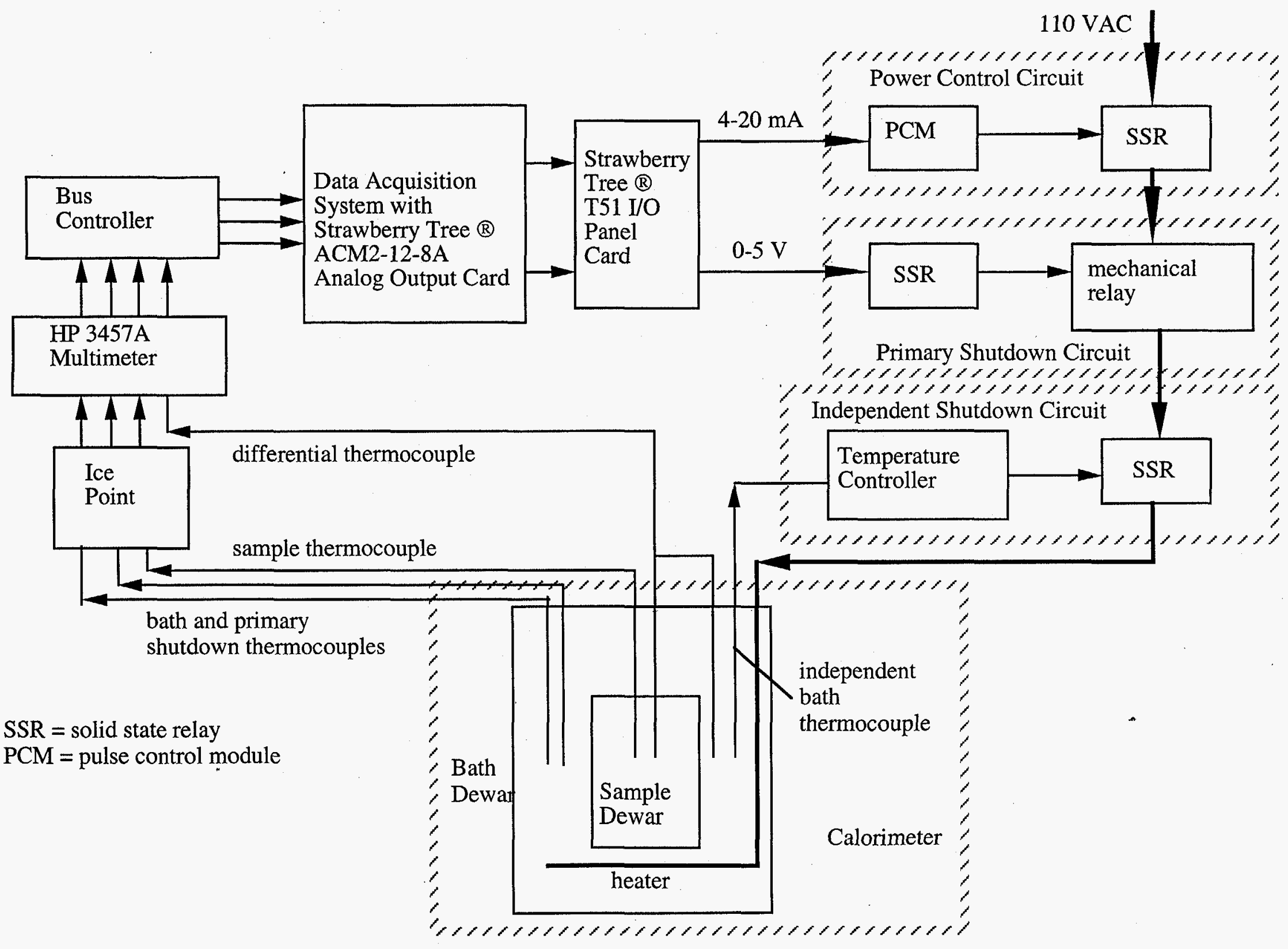

Figure 4 Schematic of Calorimeter Controller 
start time 25-Jun-97 10:38:08

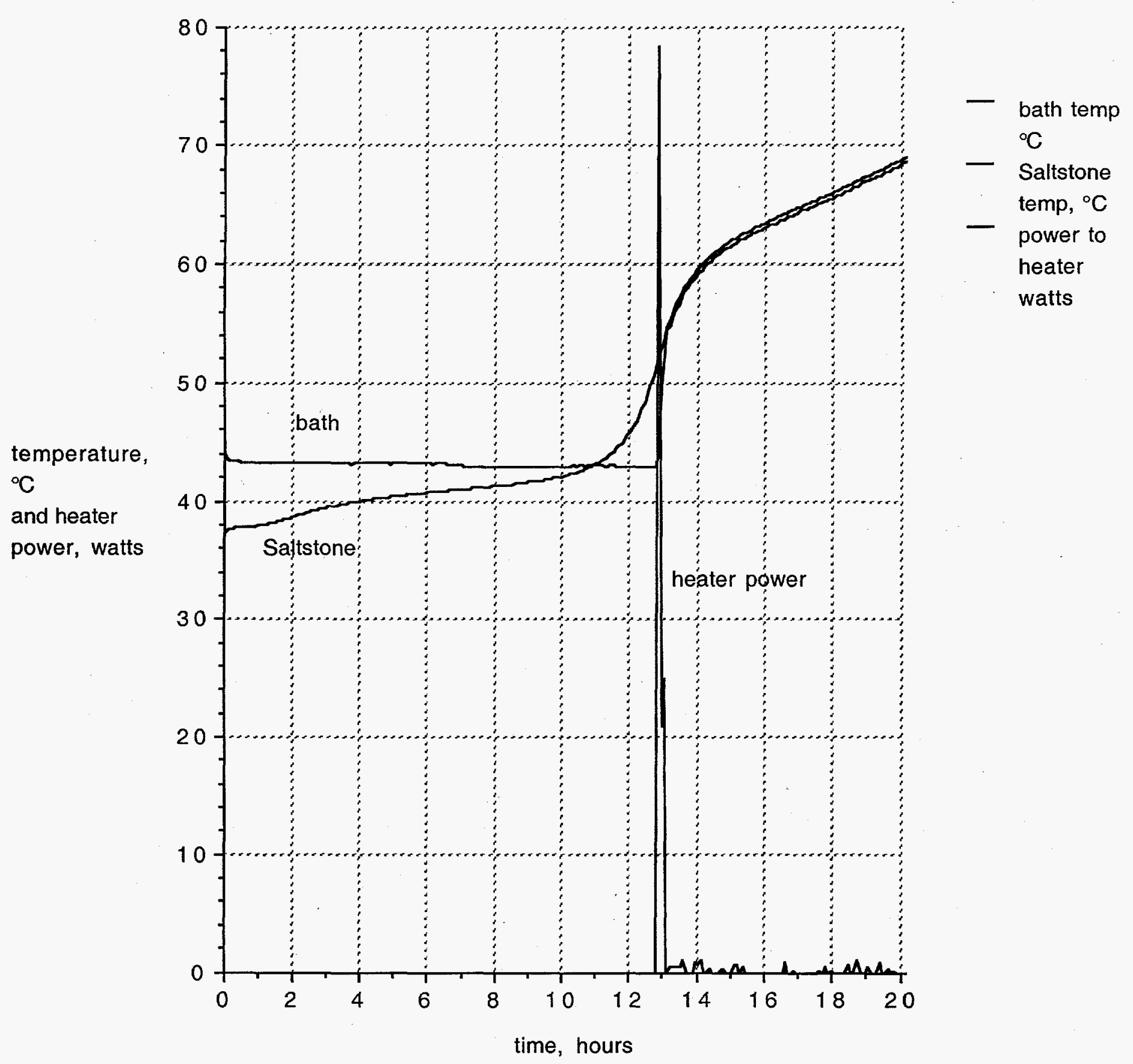

Figure 5

Example of Temperature Control for Calorimeter 


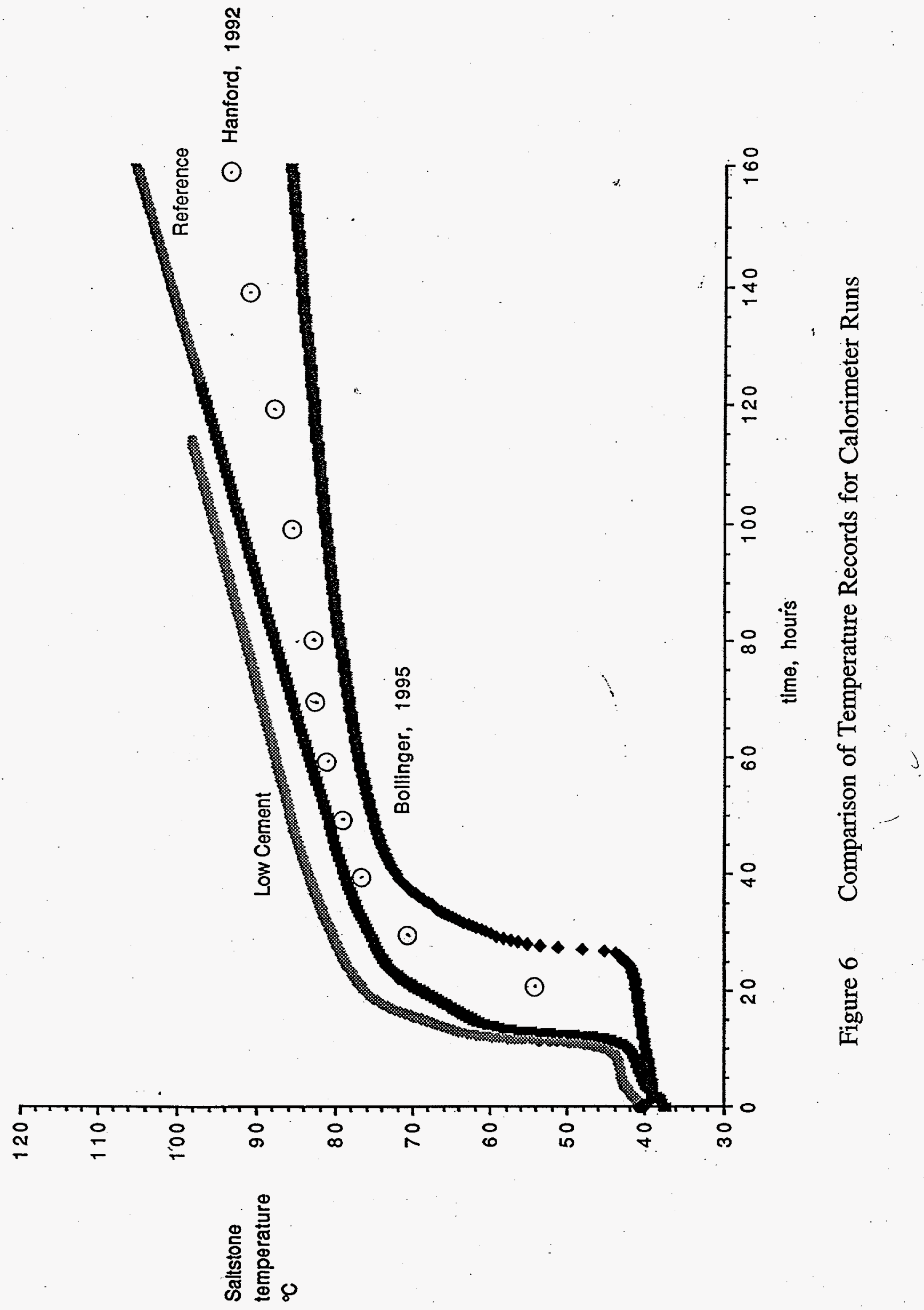




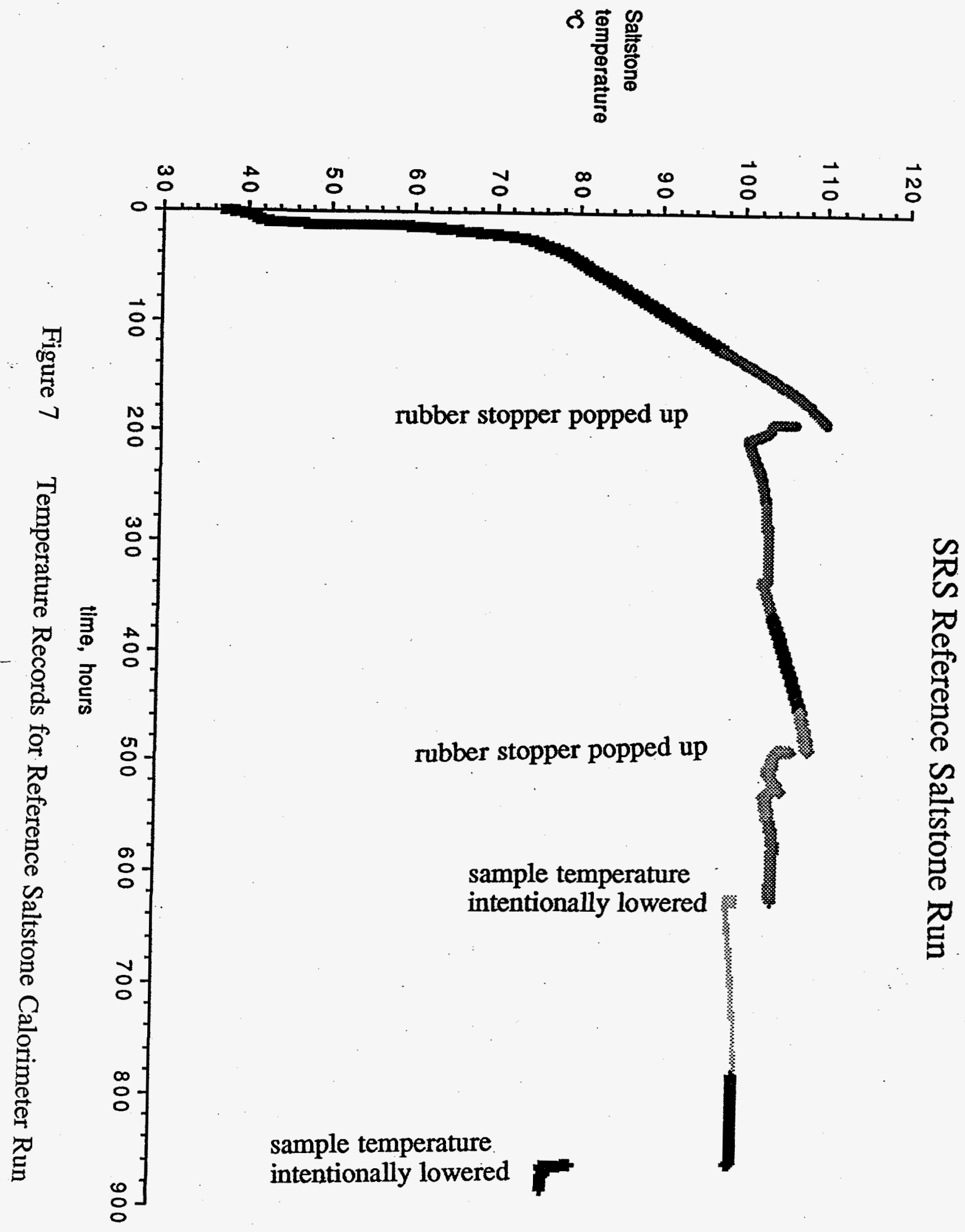


$\log 10$

heat of

hydration

W/kg

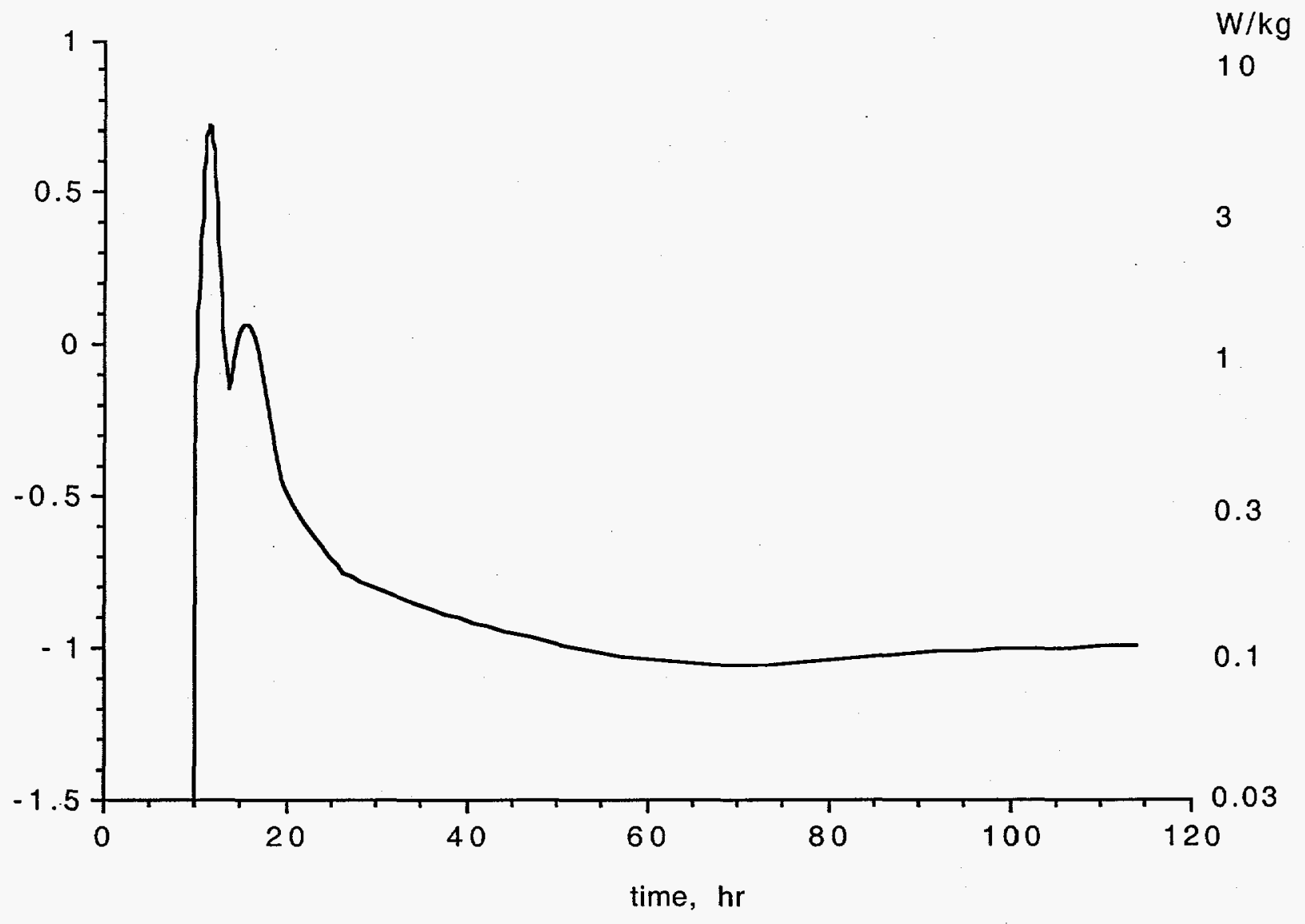

Figure 8 Heat of Hydration for Low Cement Saltstone 


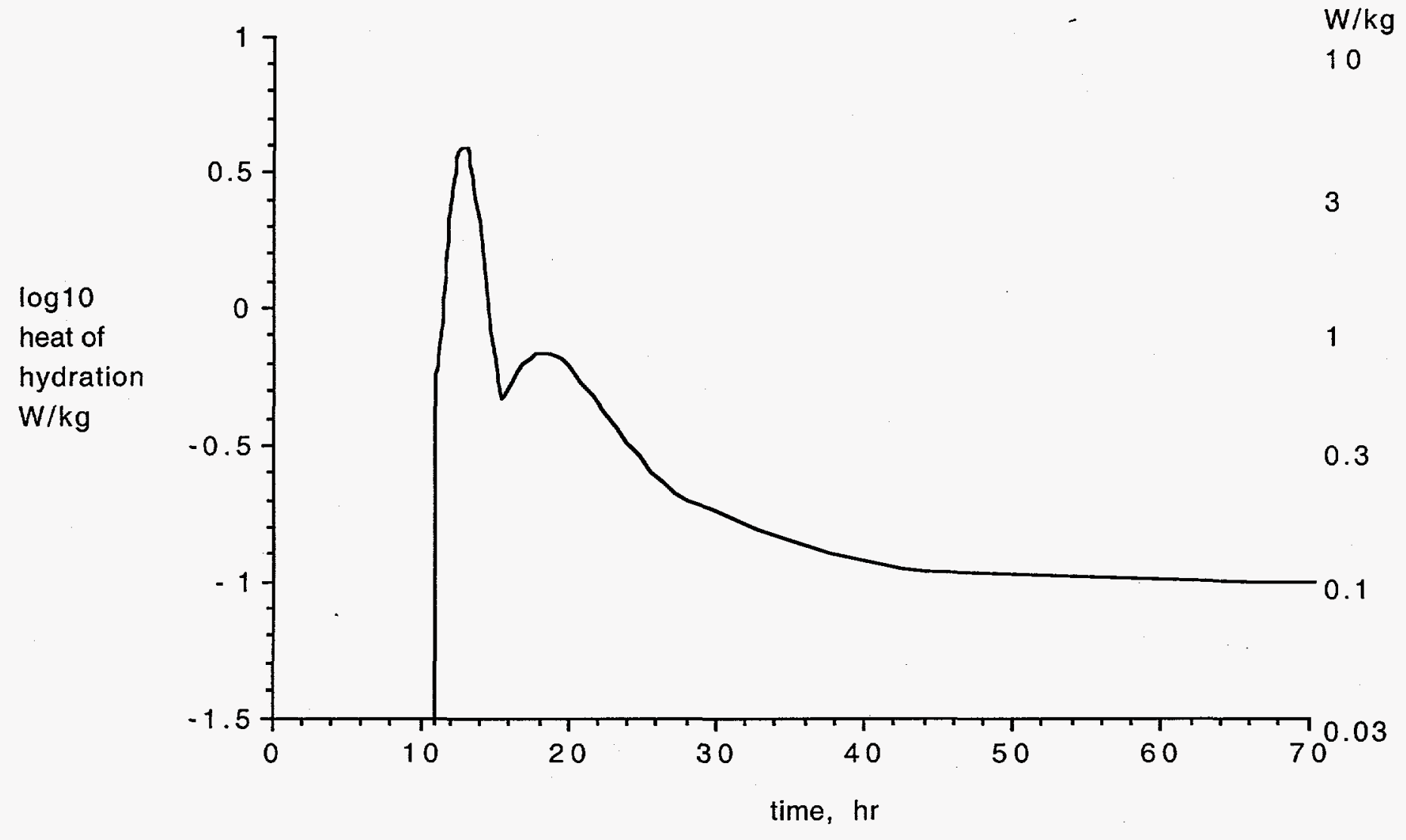

Figure 9 Heat of Hydration for SRS Reference Saltstone, Short Times

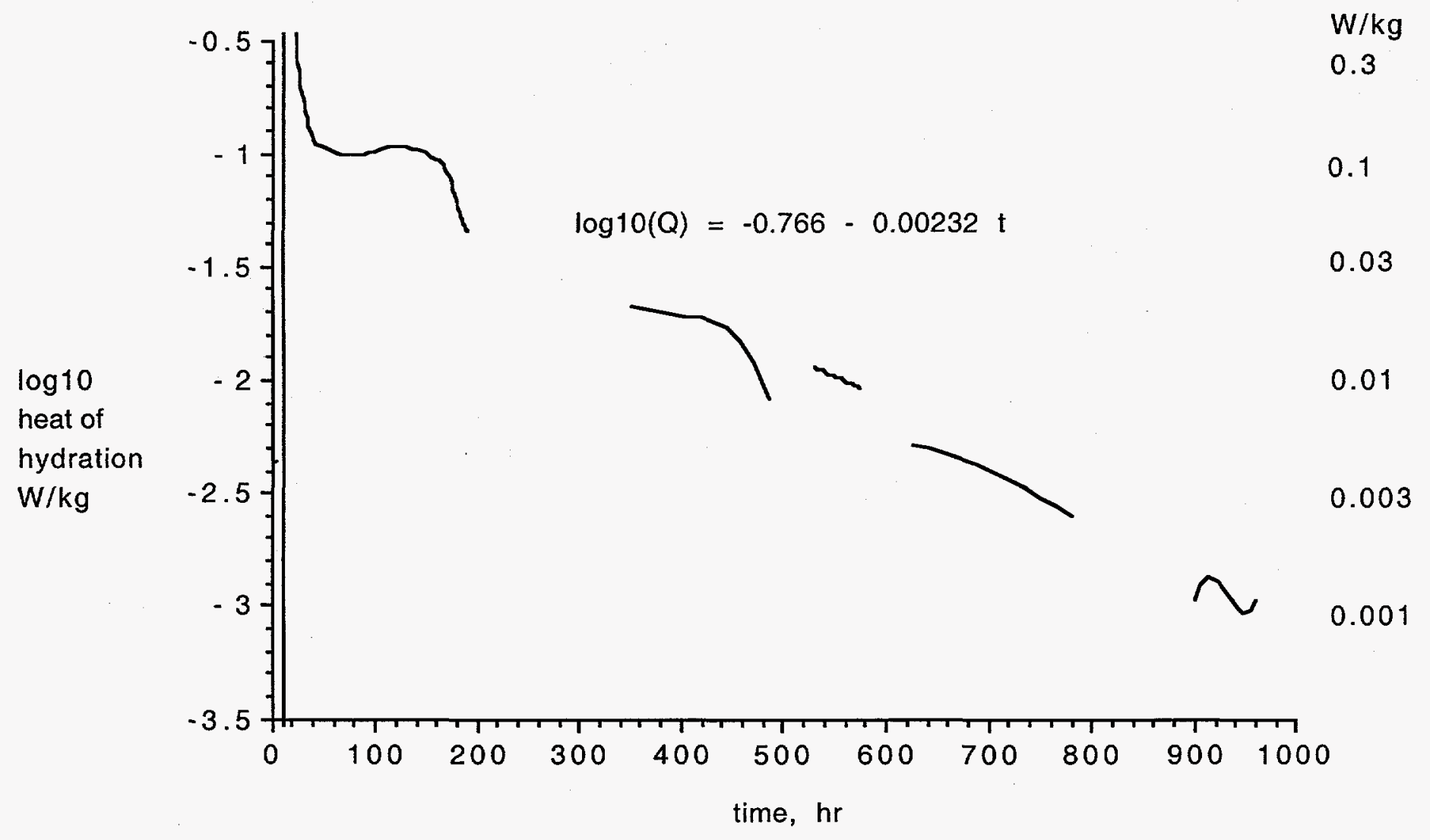

Figure 10 Heat of Hydration for SRS Reference Saltstone, Long Times 


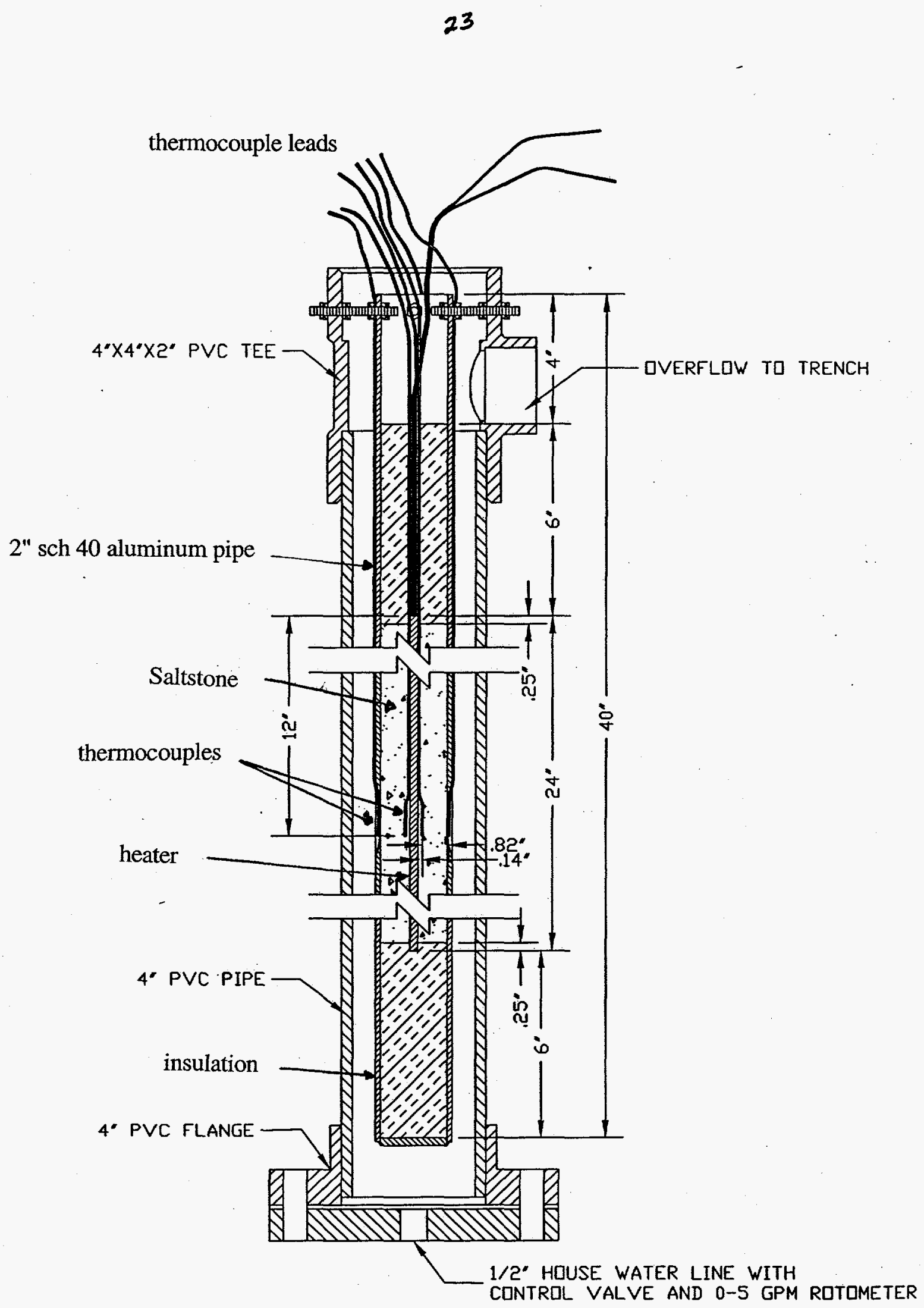

Figure 11 Side View of Cylindrical Thermal Conductivity Apparatus 


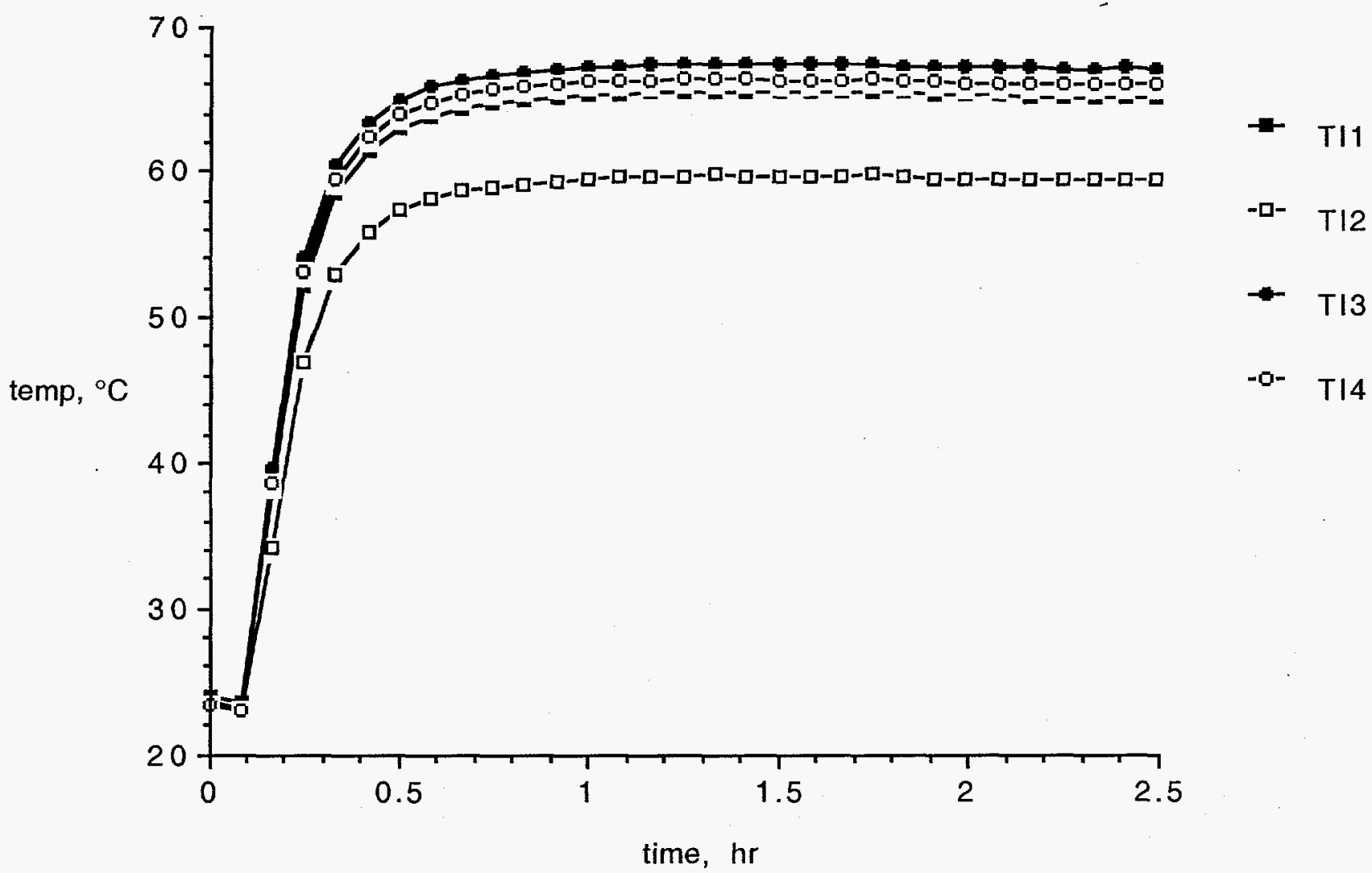

Figure 12 Temperature Transient in Cylinder of Saltstone, Inner Thermocouples

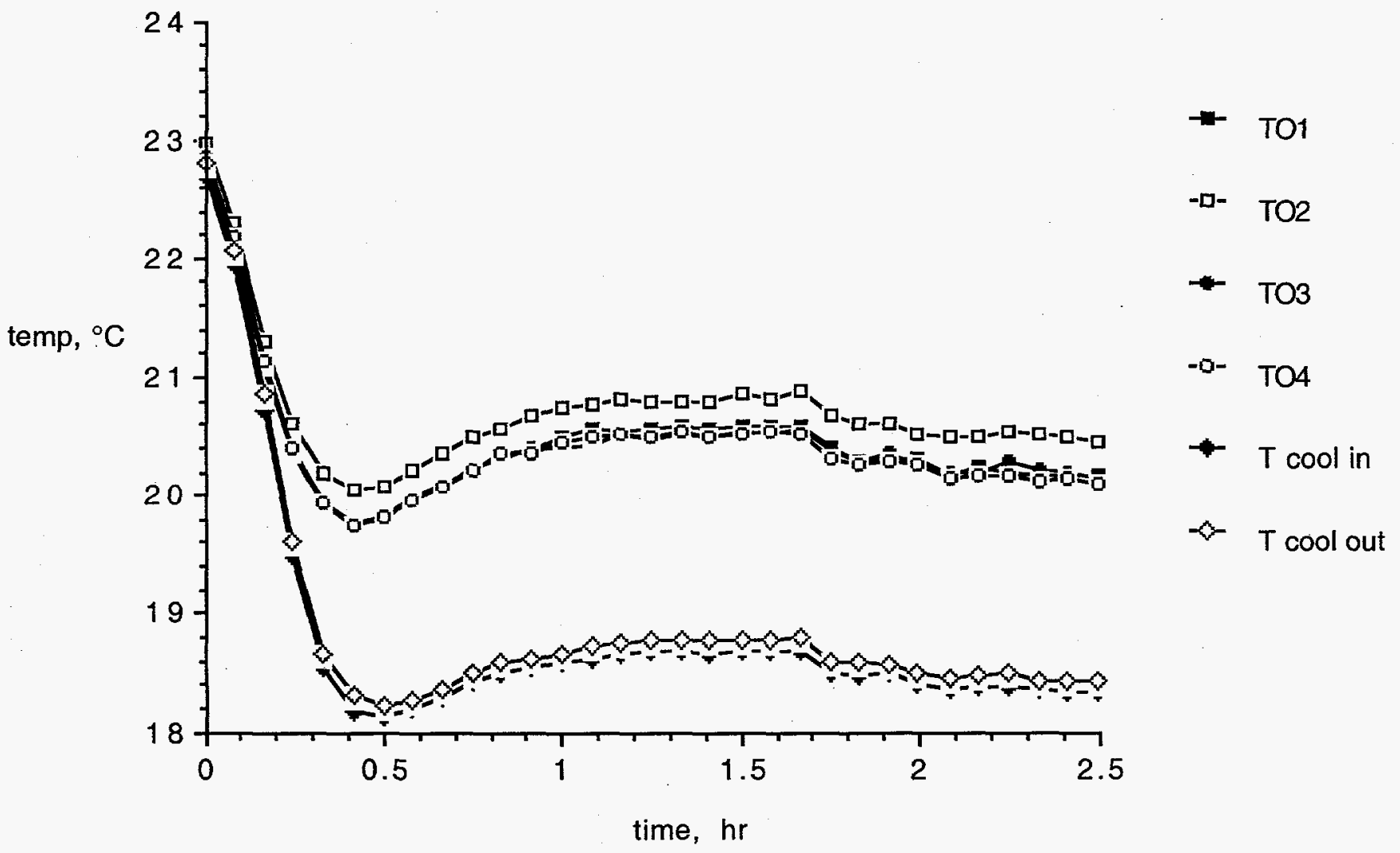

Figure 13 Temperature Transient in Cylinder of Saltstone, Outer Thermocouples 


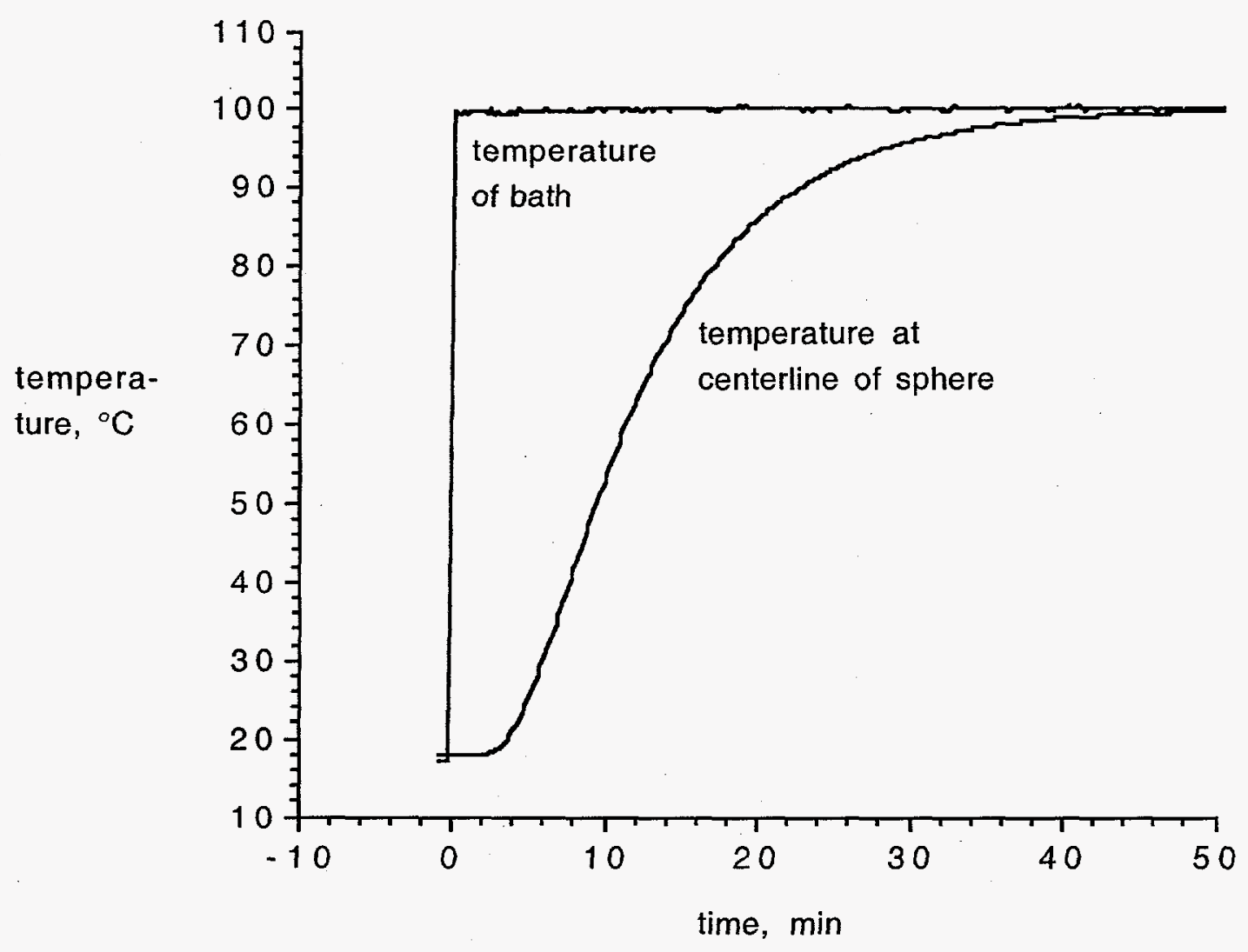

Figure 14 Temperature Transient in Sphere of Saltstone

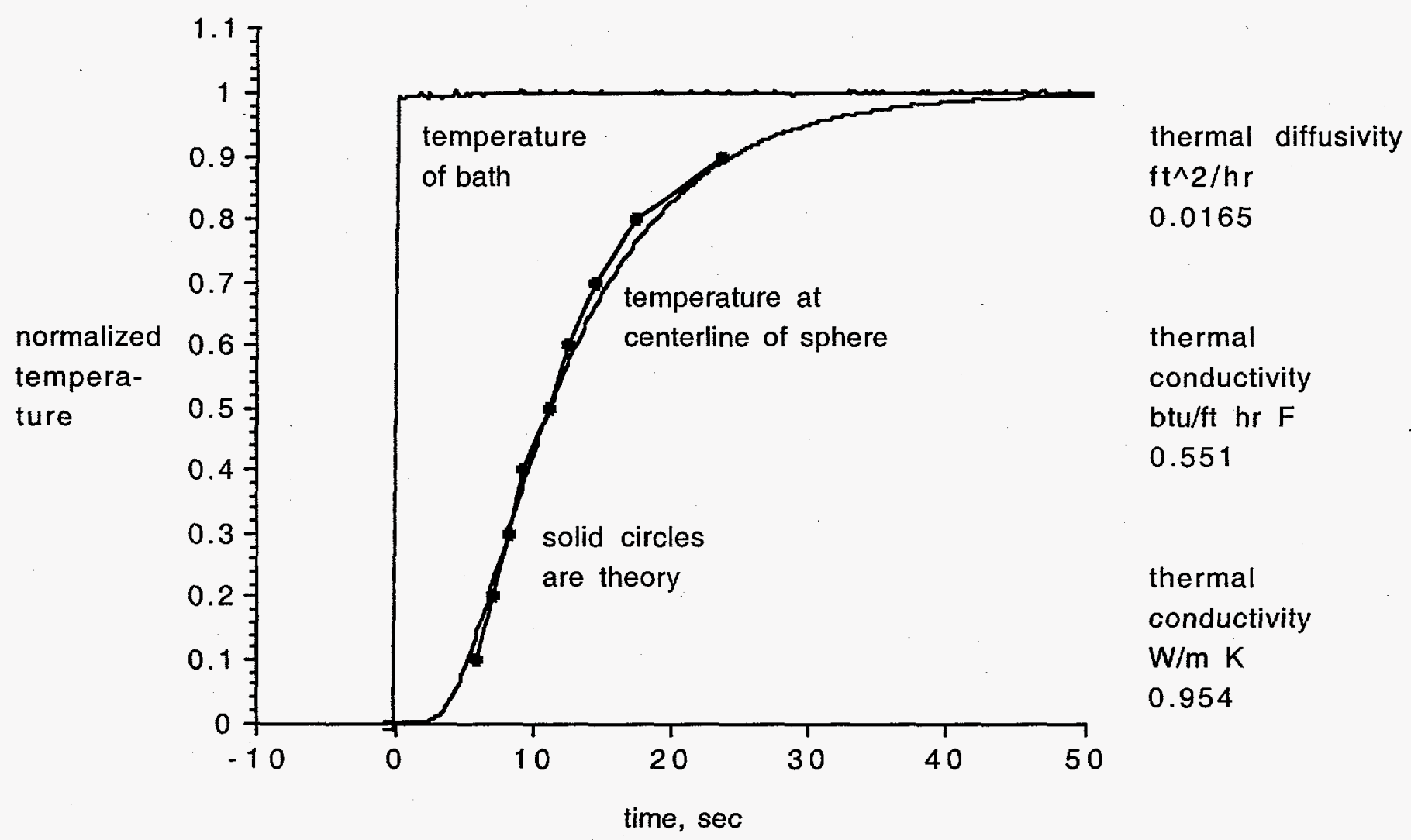

Figure 15 Normalized Temperature Transient in Sphere of Saltstone 


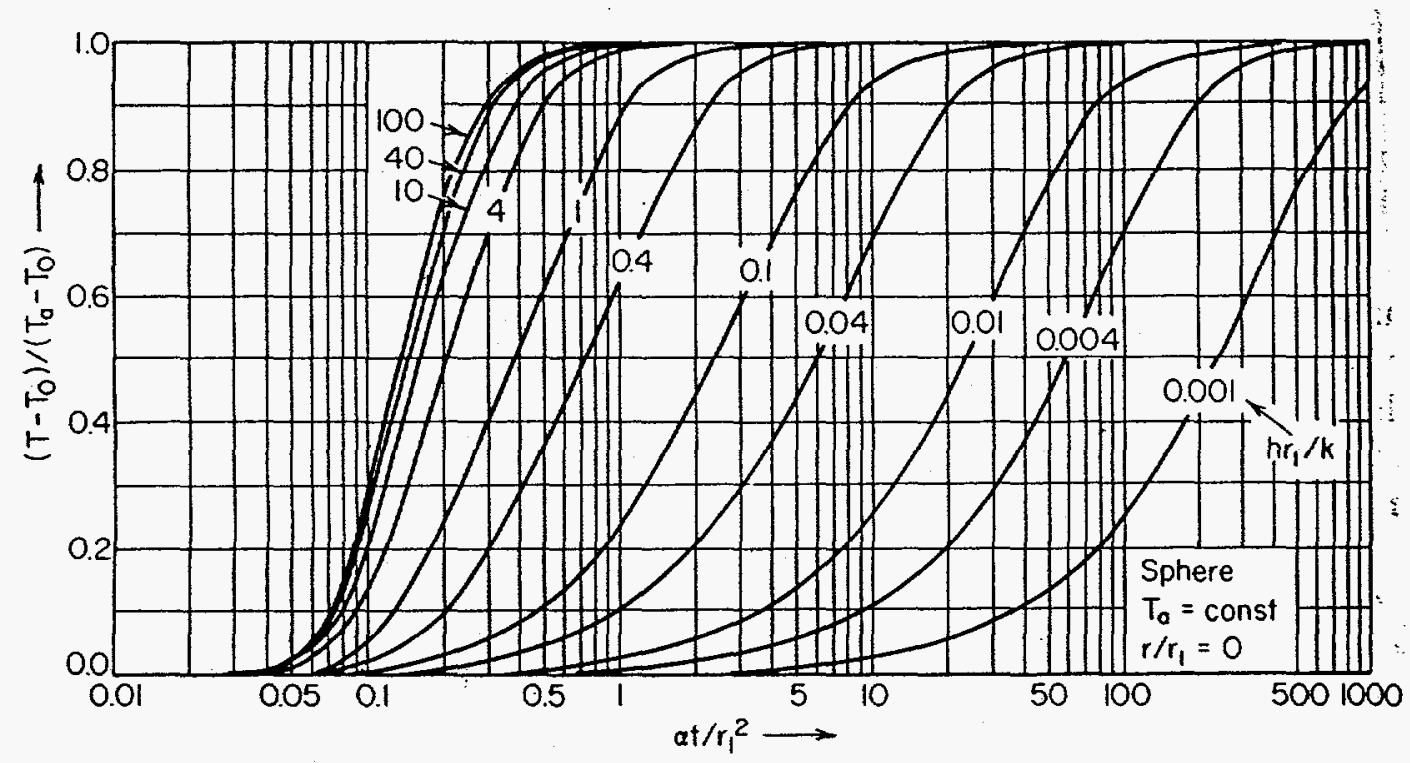

Figure 16 Temperature Response at the Center of a Solid Sphere After the Surface is Exposed to a Uniform Convective Environment $T_{a}$

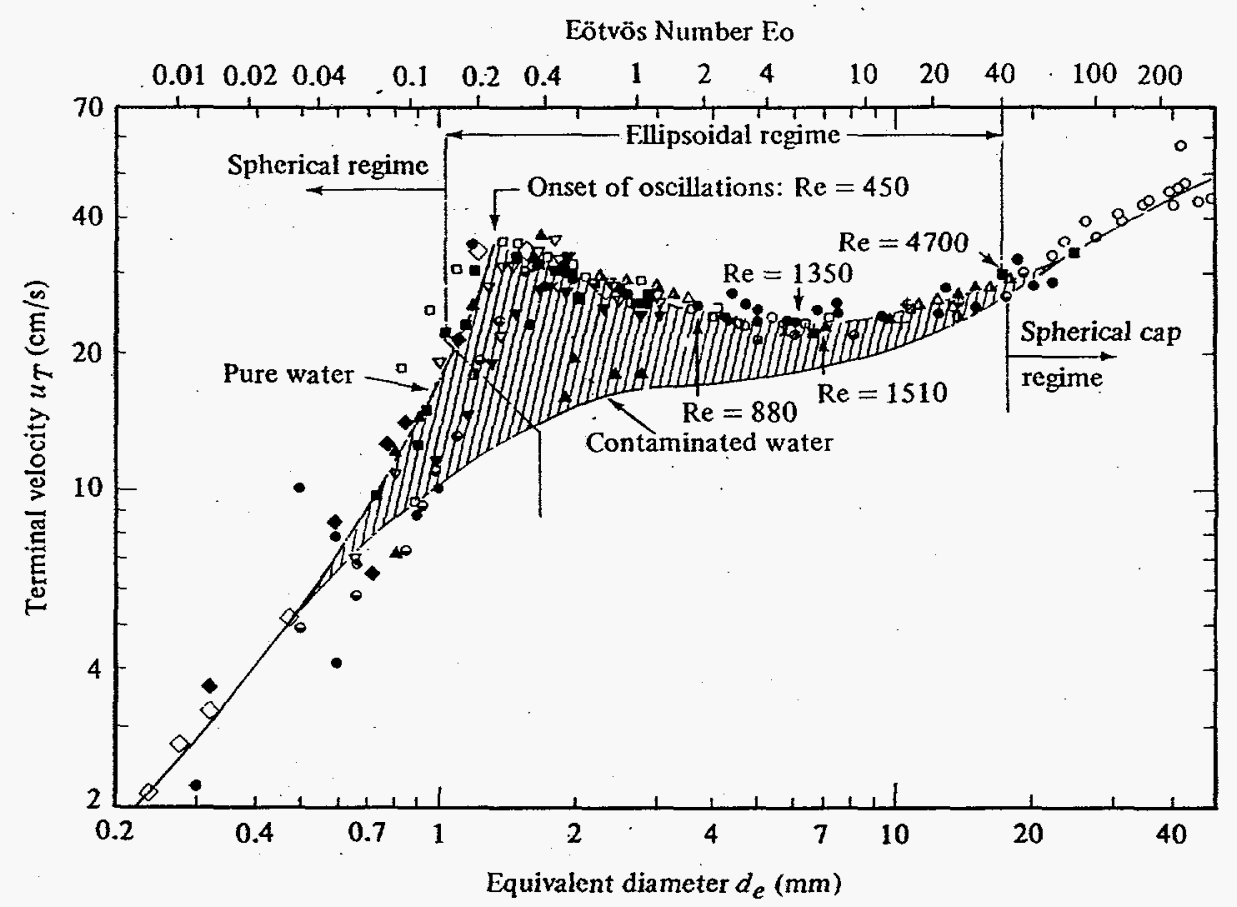

Figure 17 Terminal Velocities of Air Bubbles in Water at $20^{\circ} \mathrm{C}$ 